\title{
Hierarchy between Domestic and International Tribunals: Utopia or Near Future?
}

Date received: June $21^{\text {st }}, 2019$

Date accepted: August $26^{\text {th }}, 2020$

Doi: https://doi.org/10.12804/revistas.urosario.edu.co/acdi/a.10114

\section{Virdzhiniya Petrova Georgieva*}

Abstract: The establishment of a formal hierarchy between domestic and international tribunals has traditionally been a "taboo" for international legal scholars and operators of the domestic and international legal systems. However, it is possible and desirable to envisage hierarchy between domestic and international tribunals. Hierarchy is a strong mechanism that permits the efficient enforcement of judicial decisions and the avoidance of all types of conflicts between the judicial organs operating within a legal order. It also fosters the uniformity and predictability in the application and interpretation of the same body of legal rules by many different tribunals. Finally, hierarchy is a strong incentive for the observance of equality before the law of the actors in judicial proceedings. Both domestic and international tribunals have already used hierarchical tools when faced with the regulation of their relationships. Consequently, it appears that the establishment of a hierarchy between

\footnotetext{
* Researcher from the Instituto de Investigaciones Jurídicas and teacher of Derecho Internacional Público y Privado at the Facultad de Derecho of the Universidad Nacional Autónoma de México (UNAM). Graduate and specialist in European Union Law and International Law and Economics at Sorbonne Law School, Paris I. Master in and Doctor of Derecho Internacional at UNAM. Email: virginia.geor@derecho.unam.mx

To cite this article: Petrova Georgieva, Virdzhiniya. "Hierarchy between Domestic and International Tribunals: Utopia or Near Future?" Anuario Colombiano de Derecho Internacional (ACDI), 14 (2021): $21-71$. https://doi.org/10.12804/revistas.urosario.edu.co/acdi/a.10114
} 
domestic and international tribunals is not utopic but an ongoing trend in their judicial practice.

Keywords: International and domestic tribunals; hierarchical relations; vertical precedents; enforcement mechanisms; appeal review.

Jerarquía entre tribunales internos e internacionales: ¿utopía o futuro cercano?

Resumen: el establecimiento de una jerarquía formal entre tribunales internos e internacionales ha sido un "tabú" para los estudiosos del derecho internacional y los actores de los sistemas jurídicos interno e internacional. No obstante, es posible y deseable pensar las relaciones entre órganos judiciales internos e internacionales en términos jerárquicos. La jerarquía permite la ejecución eficaz de las sentencias de los tribunales que operan en un determinado orden jurídico y evita el surgimiento de todo tipo de conflictos entre dichas jurisdicciones. Adicionalmente, esta refuerza la uniformidad y la certeza en la interpretación y aplicación de las mismas normas y principios jurídicos por parte de múltiples y distintos tribunales. Por último, la jerarquía garantiza la igualdad ante la ley de los intervinientes en los procedimientos contenciosos ante los órganos judiciales. Tanto los tribunales internos como los internacionales ya han utilizado mecanismos jerárquicos para regular sus relaciones. En consecuencia, puede comprobarse que el establecimiento de jerarquía entre tribunales internos e internacionales no es utópica, sino una tendencia existente en su quehacer judicial respectivo.

Palabras clave: tribunales internos e internacionales; relaciones jerárquicas; precedentes verticales; mecanismos de ejecución; apelaciones.

Hierarquia entre tribunais internos e internacionais: utopia ou futuro próximo?

Resumo: o estabelecimento de uma hierarquia formal entre tribunais internos e internacionais tem sido visto como um "tabu" para estudiosos de direito internacional, assim como para os atores do sistema jurídico interno e do ordenamento jurídico internacional. No entanto, é possível 
e desejável, pensar as relações entre órgãos judiciais internos e internacionais de forma hierárquica. A hierarquia permite a execução eficaz das sentenças dos tribunais, que opera em uma determinada ordem jurídica e evita o surgimento de todo tipo de conflitos entre jurisdições. Adicionalmente, a hierarquia reforça a uniformidade e a certeza na interpretação e aplicação das mesmas normas e princípios jurídicos por parte de múltiplos e distintos tribunais. Finalmente, a hierarquia garante a igualdade perante a lei, dos envolvidos em procedimentos contenciosos perante os órgãos judiciais. Tanto os tribunais internos quanto os internacionais já utilizaram mecanismos hierárquicos para regular mutuamente suas relações. Consequentemente, pode-se comprovar que o estabelecimento de uma hierarquia entre tribunais internos e internacionais não se trata de uma evolução utópica, mas sim de uma tendência já existente em suas respectivas rotinas judiciais.

Palavras-chave: tribunais internos e internacionais; relações hierárquicas; precedentes verticais; mecanismos de execução; apelações.

\section{Introduction}

Hierarchy is the archetype of all legal reasoning. ${ }^{1}$ Law can function as a system because its parts relate to one another by complex formal and vertical relationships. All domestic legal orders are built upon normative and institutional hierarchy. Thus, the validity of a given legal system's norms derives from hierarchically higher norms. ${ }^{2}$ In the same sense, the State's legislative, executive, and judicial powers have hierarchical structures. In particular, the organization of the domestic judiciaries takes the form of a hierarchy between higher courts and lower courts, which constitutes the so-called judicial system.

In Common Law countries, the operation of the domestic judicial system's hierarchy is strengthened by the stare decisis doctrine. ${ }^{3}$ By virtue

\footnotetext{
1 Martti Koskenniemi, "Hierarchy in International Law: A Sketch.” European Journal of International Law, 8 (1997): 566. http://www.ejil.org/pdfs/8/4/785.pdf

2 Hans Kelsen, Pure theory of law. (Berkeley: University of California Press, 1967).

3 From the latin stare decisis et non quieta muovere, which means "to adhere to precedents, and not to unsettle things which are established".
} 
of this doctrine, the precedents of higher courts (vertical stare decisis) are binding to lower courts and have a normative value as a source of law. In most Civil Law systems, lower courts are not formally bound by the precedents of higher tribunals, and judges cannot create law. ${ }^{4}$ However, even in Civil Law systems, some of the decisions adopted by the highest courts in the judicial system's hierarchy — the supreme courts, such as the French Cour de cassation or the German Bundesgerichtshof - are binding and have normative value for lower courts. ${ }^{5}$ In addition, in some Civil Law systems, such as Mexico, the jurisprudence of the higher courts (the Supreme Court of Justice and the circuit tribunals) can become binding for lower courts under some strict conditions. ${ }^{6}$

The hierarchical character of judicial systems in Common Law and Civil Law countries also depends on the existence of review mechanisms of the decisions of lower courts by a higher tribunal. Higher judicial bodies can reverse lower courts' errors in the interpretation and application of legal norms and principles in particular cases brought to their jurisdiction. By so doing, higher courts avoid judicial conflicts that can affect the security and predictability, which are fundamental values of the legal system. ${ }^{7}$ In the same sense, the hierarchical coordination of the judicial activity of the tribunals that operate in domestic legal systems ensures that lower courts will effectively enforce the decisions of higher tribunals.

Written or unwritten provisions of domestic (in most cases, constitutional) law expressly regulate and centralize the domestic judicial systems upon these hierarchical principles. Nevertheless, what would happen if there were no written or unwritten legal norms to rule the vertical relationship between courts and tribunals that belong to the

4 As an example of the prohibition for judges to create law, the French Civil Code article 5 establishes: "Judges are forbidden to decide cases submitted to them by way of general and regulatory provisions."

5 In particular, when these higher courts respond to a new legal question or adopt a new solution to a problem solved in their previous caselaw and, therefore, carry out a "revirement de jurisprudence" or a "judicial overrule", their decisions become binding for lower courts.

6 According to article 107 of the Mexican Constitution: "XIII. The law shall specify the terms and cases in which the precedents of the courts of the federal judicial branch are binding, as well as the requirements for their modification."

7 Jonathan Kastellec, The Judicial Hierarchy: A Review Essay. (Oxford Research Encyclopedia of Politics), 4. https://doi.org/10.1093/acrefore/9780190228637.013.99 
same legal system? Is a non-hierarchical organization of judicial bodies possible in a legal order, or would it bring it to chaos?

The international legal order proves that many courts and tribunals can co-exist without any hierarchical relationship. In fact, even if international law has suffered for more than three centuries from the unavailability of independent and impartial judicial bodies, ${ }^{8}$ we are now living in the era of the "judicialization" of international law. ${ }^{9}$ During the end of the twentieth century and at the beginning of the twenty-first, the proliferation of international courts and tribunals fundamentally changed the landscape of dispute settlement in international law. At the beginning of the twentieth century, there were no more than three active international judicial bodies and, at present, at least fifty organs perform an international judicial or quasi-judicial function. ${ }^{10}$ However, these fifty organs do not have any formal or hierarchical link one to another, and international law does not contain any written or unwritten rule on the organization of the jurisdictional relations between international courts and tribunals. ${ }^{11}$ No higher or supreme court can overview the decisions of lower tribunals if they committed errors in the application and interpretation of international law, and there is no obligation for any lower court to follow binding precedents of a higher one. ${ }^{12}$ In summary, a hierarchical judicial system does not exist in the international legal order.

8 Georges Michel Abi Saab, "The Normalization of International Adjudication: Convergence and Divergence." New York University Journal of International Law and Politics, 43 no. 1 (2010): 1-4. https://nyujilp.org/wp-content/uploads/2013/02/43.1-Abi-Saab.pdf

9 Antonio Augusto Cancado Trindade, La expansión de la jurisdicción internacional y su importancia para la realización de la justicia. http://legal.un.org/avl/ls/Cancado-Trindade_HR_video_2.html; Virginia Petrova Georgieva, “La 'judicialización’: una nueva característica del orden jurídico internacional". Anuario Mexicano de Derecho Internacional, 15 no. 1 (2015): 3-45. https://doi.org/10.1016/j.amdi.2015.06.001

10 Roger Alford, “The Proliferation of International Courts and Tribunals: International Adjudication in Ascendance." Proceedings of the American Society of International Law Annual Meeting, 94 (2000): 160-165. https://doi.org/10.1017/S027250370005549X; Philippa Webb, International Judicial Integration and Fragmentation. (Oxford University Press, 2013).

11 Tim Graewert, "Conflicting Laws and Jurisdiction in the Dispute Settlement Process of Regional Trade Agreements and the WTO." Contemporary Asia Arbitration Journal, 1 no. 2 (2008): 290.

12 Karin Oellers-Frahm, "Multiplication of International Courts and Tribunals and Conflicting Jurisdiction- Problems and Possible Solutions." Max Planck Yearbook of 
This fact has created many practical problems for the administration of justice in international law. In the first place, the inexistence of hierarchical relationships between international tribunals has generated jurisdictional conflicts, as two or more international judicial bodies can be equally competent to solve part or the totality of a given dispute. For example, in the Sword Fish case, the conflict between Chile and the European Union was submitted, at the same time, to the International Tribunal for the Law of the Sea ${ }^{13}$ and to the Organ for Dispute Settlement of the World Trade Organization (WTO). ${ }^{14}$ In the Softwood Lumber case, that opposed Canada to the United States, the dispute was brought at the same time to a NAFTA arbitral panel and to the Organ for Dispute Settlement of the WTO. ${ }^{15}$ And, in the MOX Plant litigation, three international judicial bodies rendered binding decisions for the parties. ${ }^{16}$ Similarly, in the Genocide Case, ${ }^{17}$ the International Court of Justice (ICJ) judged Serbia and Montenegro for the genocide committed in the territory of Bosnia and Herzegovina. At the same time, the International Criminal Tribunal for the Ex-Yugoslavia (ICTY) convicted Radovan Karadzic for that same crime. ${ }^{18}$

United Nations Law, 5 (2001): 74.

13 ITLOS, Case 7: Case concerning the Conservation and Sustainable Exploitation of Swordfish Stocks in the South-Eastern Pacific Ocean (Chile/European Union), order 2/2003, December 20, 2000.

14 Wто, Chile-Measures Affecting the Transit and Importation of Swordfish, Request for the Establishment of a Panel by the European Communities, November 7, 2000

2 BvR 2115/01, Judgment, 19 September, 2006.

15 ITLOS, United States-Investigation of the International Trade Commission in Softwood Lumber from Canada, Recourse by Article 25.1 of the DSU by Canada-Report by Panel, May 9, 2006; Re Matter of Certain Softwood Lumber Products from Canada (opinion and Order), NAFTA, Extraaordinary Challenge Committee, August, 10, 2005

16 PCA, Mox Plant Case, Ireland vs. UK, June 23, 2003; ITLos, Mox Plant Case, Irlanda c. el Reino Unido, 13 de noviembre de 2001, CJE, Mox Plant Case, Commission vs.. Irland, case C-459/03, May 30, 2006.

17 ICJ, Case concerning the Application of the Convention on the Prevention and Punishment of the Crime of Genocide, Bosnia and Herzegovina vs. Serbia and Montenegro, February 26, 2007, http://www.icj-cij.org/docket/files/91/13685.pdf

18 ICTY, Prosecutor vs. Radovan Karadzic, indictment "Srebrenica”, November 24, 1995; indictment "Bosnia and Herzegovina", July 24, 1995, http://www.icty.org/case/kara$\mathrm{dzic} / 4$ 
In the second place, the lack of hierarchical rules to regulate the jurisdictional relations between international tribunals is responsible for the emergence of conflicting international jurisprudence. As pointed by the Inter-American Court of Human Rights (IACHR) in its Consultative Opinion on the Right to Information on Consular Assistance:

in every legal system, it's a normal phenomenon that tribunals that don't have hierarchical relations can (...) interpret the same body of law. Consequently, it's not surprising that they can reach divergent, or at least, different conclusions on the same rule of law. ${ }^{19}$

By so doing, in the Tadic case,${ }^{20}$ the ICTY sustained opposite views to the ICJ in the case concerning Military and Paramilitary Activities in Nicaragua. ${ }^{21}$ The ICJ, in the Avena case, considered that the right to information on consular assistance, provided by article 36 of the Vienna Convention on Consular Relations, does not constitute a human right and the IACHR, in the above-mentioned Consultative Opinion, ruled that it is one. ${ }^{22}$ In Hoechst AG $v /$ Commission case, ${ }^{23}$ the European Court of Justice (ECJ) found that the right to privacy, established in article 8 of the European Convention on Human Rights, cannot be extended to the business activities of private persons. The ECHR, on its part, in Niemietz v/ Germany, ${ }^{24}$ ruled that it can. The Orkem v/ Commission ${ }^{25}$ case of the ECJ and the Funke vs. France ${ }^{26}$ case of the ECHR also showed divergent

19 IACHR, Opinión consultiva OC-16/99, "El derecho a la información sobre la asistencia consular en el marco de las garantías del debido proceso legal", 1st of November 1999, http://www.cidh.org/migrantes/Opini \%C3\%B3n\%20Consultiva \%2016.htm, párr. 61 20 ICTY, Prosecutor vs. Tadic, May 7, 1997, http://www.icty.org/x/cases/tadic/tjug/en/ tad-tsj70507JT2-e.pdf; Appeal Chamber Decisions, July 15, 1999, http://www.icty. org/x/cases/tadic/acjug/en/tad-aj990715e.pdf

21 ICJ, Military and Paramilitary Activities in Nicaragua, June 27, 1986, http://www.icj-cij. org $/$ docket $/$ index.php? sum $=367 \&$ code $=$ nus $\& \mathrm{p} 1=3 \& \mathrm{p} 2=3 \& \mathrm{case}=70 \& \mathrm{k}=66 \& \mathrm{p} 3=5$

22 ICJ, Avena, México vs. United States, March 31, 2004, en http://www.icj-cij.org/ docket/files/128/8188.pdf

23 Cases 46/87 y 227/88

24 December 6, 1992.

25 Case 374/87.

26 February 25, 1993. 
interpretations and applications of the right to the due process of law, recognized in article 6 of the European Convention on Human Rights. ${ }^{27}$

Although domestic and international courts are not part of the same legal system, the problems related to the regulation of the relations between them are similar to those faced by the interactions between international tribunals alone. In the early stages of the development of the international legal order, domestic and international tribunals operated in almost complete isolation from one another. Nowadays, international law has permeated the national legal orders, and domestic and international tribunals are part of a constant interplay. In the first place, domestic tribunals are entitled to fulfill an international judicial function. National judges perform an international judicial function every time they have to recourse to international law as a legal basis for the dispute settlement of the cases brought to their jurisdiction. ${ }^{28}$ In that sense, domestic judges are complementary to international tribunals, as they also have jurisdiction over cases related to the interpretation and application of international law. ${ }^{29}$ In the second place, domestic tribunals are State agents and, as such, are obliged to enforce the judgments of international tribunals at the domestic level. International tribunals cannot dispose of the use of coercive power within the territory of the States, so they are always "dependent" on domestic tribunals regarding this issue. Therefore, domestic tribunals are actually the "bras fort" of the international tribunals.

This interplay between domestic tribunals and their international counterparts suffers from the lack of hierarchical institutional links in the same way that the interaction between international judicial bodies does. There are no written rules neither on domestic nor international law that establish superiority or inferiority between them. No higher courts

\footnotetext{
27 August Reinisch, "The Use and Limits of Res Judicata and Lis Pendens as Procedural Tools to Avoid Conflicting Dispute Settlement Outcomes." Law and Practice of International Courts and Tribunals, 3 no. 1 (2004): 37-77. https://doi.org/10.1163/157180301773732627

28 Antonios Tsanakopoulos, "Domestic Courts in International Law: The International Judicial Function of National Courts." Loyola of Los Angeles International \& Comparative Law Review, 34 (2011): 133-168. https://ssrn.com/abstract=1861067

29 André Nollkaemper, "Conversations Among Courts, Domestic and International Adjudicators." In The Oxford Handbook of International Adjudication, edited by Cesare Romare, Karen Alter and Yuval Shany. (Oxford University Press, 2015). https://doi. org/10.1093/law/9780199660681.003.0024
} 
(domestic or international) can control the interpretation and application of international law norms and principles in the decisions of lower courts (domestic or international). No court (domestic or international) has been legally settled as a supreme court that can assure the uniformity of the judicial activity of other (international or domestic) tribunals. In principle, the stare decisis rule does not apply in the relations between international and domestic tribunals. The judicial organs, which operate in the domestic and international legal orders, are in law completely autonomous and independent from one another and do not have any formal obligation to coordinate their judicial functions.

That situation has created, as well, different types of conflicts between domestic and international tribunals that might seem irrational and unfair. To begin with, both tribunals have issued conflicting decisions on the interpretation and application of the same international law norms and principles. For example, the Avena saga gave way to conflicting decisions of two international tribunals and two domestic judicial organs. As mentioned above, the IACHR considered that the right to information on consular assistance, recognized in article 36 of the Vienna Convention on Consular Relations, constitutes a human right and the ICJ, in the Avena case, observed "that neither the text nor the object and purpose of the Convention, nor any indication in the travaux préparatoires, support" that conclusion. ${ }^{30}$ In conflict with the IACHR decision, a New Mexico, United States' (Us) Court ${ }^{31}$ rejected the ICJ's interpretation and considered that the article does not afford individual rights to private persons. In accordance with the IACHR, and against the findings of the ICJ, the Mexican Supreme Court in the Florence Cassez case ${ }^{32}$ ruled that the right to information on consular assistance is a "fundamental right" for all foreign citizens. ${ }^{33}$

The Ferrini $i^{34}$ saga is another important example of the negative consequences of the lack of hierarchical relations between domestic and international tribunals. The Italian Corte di Cassazione admitted a demand against Germany regarding the jurisdictional immunity of that State

\footnotetext{
30 Avena case, para. 124.

31 State v. Ricardo Martinez-Rodriguez, 33 P.3d 267 (N.M. 2001).

32 Amparo Directo 517/2011, January 23, 2013.

33 Florence Cassez case, para 173.

34 Italian Supreme Court, Case number 5044, Luigi Ferrini vs. Germany, 11 March 2004.
} 
in international law and considered that it is not applicable in cases of violation of ius cogens rules, such as the prohibition of torture or forced labor. The ICJ, in the case Jurisdictional Immunities of the State, ${ }^{35}$ found that neither conventional nor customary international law admit an exception to the jurisdictional immunity of sovereign States for acts committed in violation of ius cogens rules. Similarly, the ECJ, in the Kobler ${ }^{36}$ case, recognized the responsibility of the European Union (EU) member States for contraventions of EU law, resulting from the decision of a domestic tribunal. The French Conseil d'État, in a 2008 decision, ${ }^{37}$ observed that it was impossible to recognize the responsibility of States for a national judgment that constituted res indicata.

Another problem created by the lack of hierarchy in the relations between domestic and international tribunals has to do with the enforcement of the decisions of international tribunals within the domestic legal order. This enforcement is essential for the authority of the judgments of international tribunals and is an obligation of all States' organs, by virtue of international law. However, the determination of the binding character of the duty to enforce these sentences also depends on domestic law, ${ }^{38}$ and those do not usually establish the duty of domestic courts to act as "organs of enforcement" of the decisions of international tribunals. ${ }^{39}$ Moreover, domestic judges themselves have the ultimate power to determine the effect of international judgments in the domestic legal order. The vague or distant character of domestic law regarding the obligation of national courts to enforce the decisions of international tribunals has favored the emergence of "resistance" techniques by some domestic courts. Again, in the Avena saga, the us Supreme Court of Justice, in the Medellin case, considered that the ICJ judgment, in the Avena sentence, was not directly enforceable and could

\footnotetext{
35 ICJ, Jurisdictional Immunities of the State, (Germany v Italy), 3rd February 2012.

36 ECJ, Köbler vs. Austria (2003) C-224/01.

37 Conseil d'Etat, décision, 18/06/2008, Gestas.

38 Yuval Shany, Regulating Jurisdictional Relations Between National and International Tribunals. (Oxford University Press, 2009), 82-83.

39 Moreover, the domestic systems of some dualistic countries, such as Bulgaria, for example, establish that to be binding in the domestic legal order, the judgments of international tribunals need to be separately incorporated in the domestic law, by a special internal legislation. Nollkaemper, "Conversations Among Courts...", p. 533.
} 
not produce direct effects before us Courts unless it was incorporated by binding federal legislation. ${ }^{40}$ In a decision rendered after the LaGrand case, the German Constitutional Court considered that the decisions of the ICJ are not "unconditionally" binding for domestic tribunals and can be set aside if they contradict fundamental constitutional principles of German law. ${ }^{41}$ In the Ferrini saga, the Italian Corte di Cassazione rendered a second judgment after the ICJ's decision in the case concerning the Jurisdictional Immunities of the State, ${ }^{42}$ and found that Italy should not enforce that judgment as it "could not enter the Italian legal order and could not produce legal effects in Italian law". ${ }^{43}$ In the same sense, in 2008, the Venezuelan Supreme Court ${ }^{44}$ refused to enforce the decision of the IACHR in the Aptiz Barbera case ${ }^{45}$ because of its non-conformity with the Venezuelan Constitution.

The reality of these problems and the lack of rules de lega lata that can govern the relationships between international and domestic tribunals have retained the attention of international legal scholars for many decades. Some works have proposed the use of different legal tools, such as the principle of res indicata, the fork on the road clause, or the doctrine of abus de droit to regulate the jurisdictional relations between domestic and international tribunals. ${ }^{46}$ Many others have assumed that the best way to rule this relationships is to leave them open for the development of a horizontal and informal interaction between domestic and international tribunals based on the transnational judicial dialogue ${ }^{47}$ and

\footnotetext{
40 US Supreme Court, Medellin vs. Texas, 552 U.S. 491 (2008).

412 BvR 2115/01, Judgment, 19 September.2006.

42 Italian Constitutional, Court No. 238, 22 October 2014.

43 Fulvio Maria Palombino, "Compliance with International Judgments: Between Supremacy of International Law and National Fundamental Principles." ZAÖRV, 75 (2015): 506. https://www.zaoerv.de/75_2015/75_2015_3_a_503_530.pdf

44 Venezuelan Supreme Court, decisión No. 1939 del 18 de diciembre de 2008.

45 IACHr, Apitz-Barbera et al. vs. Venezuela, 5 August 2008.

46 Yuval Shany, Regulating Jurisdictional Relations..., 146-ss.

47 Cesare Romano, "Deciphering the Grammar of the International Jurisprudential Dialogue." New York University Journal of International Law and Politics, 41 no. 4 (2010): 755-787. http://cesareromano.com/wp-content/uploads/2015/05/Romano-Dechiphering-Grammar-of-the-Jurisprudential-International-Dialogue.pdf; Christine Chanet, "Les influences croisées entre les juridictions nationales et les juridictions internationales.” Les Cabiers de Droit, 51 no. 1 (2010): 223-232. https://doi.org/10.7202/044141ar;
} 
the comity approach. ${ }^{48}$ By an informal and spontaneous coordination based on mutual deference, respectful consideration, cross-references, cross-fertilization, and mutual acculturation, domestic and international tribunals could avoid jurisdictional overlaps and conflicting judgments and would engage in the construction of a transnational judicial network ${ }^{49}$

Claire L’Heureux-Dubré, «The Importance of Dialogue: Globalization and the International Impact of Rehnquist Court». Tulsa Law Journal, 34 no. 1 (1998): 15-40; Anne Marie Slaughter, "Judicial Globalization.” Virginia Journal of International Law, 40 no. (1999): 1103-1124. https://scholar.princeton.edu/sites/default/files/slaughter/files/vjil. pdf; Anne Marie Slaughter, "A Typology of Transjudicial Communication." University of Richmond Law Review, 29 no. 1 (1995): 99-137; Melissa Waters, "Mediating Norms and Identity: The Role of Transnational Judicial Dialogue in Creating and Enforcing International Law." Georgetown Law Journal, 93 no. 2 (2005): 487-574. https://ssrn.com/abstract=794767; Romano Orrù, Informal Judicial Cross-Fertilization and the System of Conferences Between Constitutional Courts and Equivalent Bodies. http://www.juridicas.unam.mx/wccl/ ponencias/12/206.pdf; Jean du Bois de Gaudusson, "La complexité de la participation des Cours suprêmes des pays en voie de développement au dialogue des juges." Petites affiches, no. 112, June 4, 2008, 22.; Jullie Allard and Antoine Garapon, Les juges dans la mondialisation - la nouvelle révolution du droit. (Paris: Le Seuil, 2005); Benoît Frydman, "Le dialogue international des juges et la perspective idéale d'une justice universelle." In Le dialogue des juges, Actes du colloque du 28 avril 2006. Bruxelles: Bruylant, 2007.

48 Anne-Marie Slaughter, A New World Order. (Princeton University Press, 2005), 65-103, 144-51; Robert B. Ahdieh, "Between Dialogue and Decree: International Review of National Courts" New York University Law Review, 79 no. 5 (2004): 2029. https:// www.nyulawreview.org/wp-content/uploads/2018/08/NYULawReview-79-6-Ahdieh. pdf; Roger P. Alford, "Federal Courts, International Tribunals, and the Continuum of Deference." Virginia Journal of International Law 43 (2003): 675-796; Jose E. Alvarez, "The New Dispute Settlers: (Half) Truths and Consequences." Texas International Law Journal, 38 no. 3 (2003): 405-455; William W. Burke-White, "A Community of Courts: Toward a System of International Criminal Law Enforcement." Michigan Journal of International Law, 24 no. 1 (2002): 1-104. https://repository.law.umich.edu/mjil/vol24/ iss1/1/; Laura A. Dickinson, "Using Legal Process to Fight Terrorism: Detentions, Military Commissions, International Tribunals, and the Rule of Law." South Carolina Law Review, 75 (2002): 1407-1492. https://southerncalifornialawreview.com/wp-content/ uploads/2018/01/75_1407.pdf; Laurence R. Helfer, “Overlegalizing Human Rights: International Relations Theory and the Commonwealth Caribbean Backlash Against Human Rights Regimes.” Columbia Law Review, 102 no. 7 (2002): 1832-1911; Laurence R. Heifer \& Anne-Marie Slaughter, "Toward a Theory of Effective Supranational Adjudication." The Yale Law Journal, 107 no. 2 (1997): 273-391; Julian G. Ku, "International Delegations and the New World Court Order." Washington Law Review, 81 no. 1 (2006): 1-70. https://digitalcommons.law.uw.edu/wlr/vol81/iss1/2

49 Monica Claes y Maartje de Visser, "Are You Networked Yet? On Dialogues in European Judicial Networks.” Utrecht Law Review, 8 no. 2 (2012): 100-114. http://doi. 
or a global community of Courts. ${ }^{50}$ In these authors' opinions, the relations between international and domestic tribunals (and international tribunals alone) can be settled by an interdependent, auto-coordinated, informal, and non-hierarchical judicial structure in which every tribunal would be an interlinked "noodle". 51 The picture painted by prominent international scholars regarding the relationship between international and domestic tribunals is, in sum, one of "complementarity and dialogue, rather than opposition and hierarchy". 52

Nevertheless, as the above cases show, these non-hierarchical models of coordination of the judicial activity of domestic and international tribunals have failed to explain the persistence of conflicts between them. Some domestic and international tribunals do not seem to be fully convinced of the role they should play in the comity model and the place they should occupy in a "transnational judicial network". These conflicts prove that the constructive judicial dialogue might be broken when domestic tribunals refuse to cede power to their international counterparts and do not accept international judges' authority "to tell them what to do".

However, the establishment of a formal hierarchy between domestic and international tribunals has traditionally been a "taboo" for international legal scholars and legal operators of the domestic and international legal systems. Some authors have proposed a hierarchical system to rule the interaction between international tribunals alone. ${ }^{53}$ This vision

org/10.18352/ulr.197; Anne Marie Slaughter, "Sovereignty and Power in a Networked World Order." Standford Journal of International Law, 40 (2004): 285. https://scholar. princeton.edu/sites/default/files/slaughter/files/stanford.pdf ; Anne-Marie Slaughter, "A Brave New Judicial World." In American Exceptionalism and Human Rights, edited by Ignatieff, Michael, 277-303. (Princeton University Press, 2005), 275. https://doi. org/10.2307/j.ctt7skx6.12

50 Jenny Martínez, “Towards and International Judicial System.” Standford Law Review, 56 no. 2 (2003): 429-529.

51 Cesare Romano, "Deciphering the Grammar of the International Jurisprudential Dialogue," p. 757.

52 André Nollkaemper, "The Role of Domestic Courts in the Case Law of the International Court of Justice", Chinese Journal of International Law, 5 no. 2 (2006): 301-322. https://doi.org/10.1093/chinesejil/jml027

53 Gilbert Guillaume, "Advantages and Risks of Proliferation, A Blueprint for Action." Journal of International Criminal Justice, 2 no. 2 (2004): 300. https://doi.org/10.1093/ jicj/2.2.300; Giuliana Ziccardi Capaldo, The Pillars of Global Law. (New York: 
places the ICJ at the "top" of an international judicial system, which also considers that it should act as primus inter pares: an appeal court for all the other international tribunals ${ }^{54}$ that will be able to hear preliminary rulings and establish the correct way to apply and interpret international law. ${ }^{55}$ However, the possibility to introduce a hierarchy between domestic and international Courts has been either underestimated or considered as an impossible venue to rule the relations between them.

The objective of this article is to argue that it is possible and desirable to envisage a hierarchy between domestic and international tribunals. The hierarchy present in domestic judicial systems is a strong and formal mechanism that permits the efficient enforcement of judicial decisions and the avoidance of all types of conflicts between the judicial organs operating within it. It also fosters the uniformity and predictability in the application and interpretation of the same body of legal rules by many different tribunals. Finally, hierarchy is a strong incentive for the observance of equality before the law of the actors in domestic judicial proceedings.

In this sense, the article will demonstrate the existence of legal mechanisms, which can serve to organize hierarchical relations between domestic and international tribunals. Both courts can have recourse to these tools even without a formal authorization to do so by domestic or international law. These legal instruments have already been used, both by domestic and international tribunals, in the resolution of specific cases brought to their jurisdiction. Consequently, it appears that

AshgatePublishing, 2008), 95-132; Francisco Orrego Vicuña y Cristopher Pinto, The Peaceful Settlement of Disputes: Prospects for the Twenty First Century, Preliminary Report Prepared for the 1999 Centennial of the First Peace Conference. CAHDI, 1998; Gilbert Guillaume, "The Future of International Judicial Institutions." The International and Comparative Law Quarterly, 44 no. 4 (1995): 848-862; Robert Jennings, "The Proliferation of Adjudicatory Bodies: Dangers and Possible Answers in Implications of the Proliferation of International Adjudicatory Bodies for Dispute Resolution." American Society of International Law Bulletin, 7(1995); Georges Abi-Saab, "Fragmentation or Unification: Some Concluding Remarks." New York University Journal of International Law and Politics, 31 no. 4 (1999): 919-933.

54 Christian Leathely, "An institutional hierarchy to combat the fragmentation of international law: has the ILC missed an opportunity?" International Law and Politics, 40 (2007): 259-306. http://repositoriocdpd.net:8080/handle/123456789/640

55 Gilbert Guillaume, "The Future of International Judicial Institutions.” The International and Comparative Law Quarterly, 44 no. 4 (1995): 848-862. 
the establishment of a hierarchy between domestic and international tribunals is not utopic, but an ongoing trend in some of their judicial practices.

More generally, this article will show that hierarchy concerns have always been present as "non-spoken words" in the mindset of both domestic and international judges when they are faced with the regulation of their relationships. These have never been immune to power cession battles, superiority-inferiority dilemmas, and ultimate authority pronouncements, both coming from international and domestic tribunals.

The article will consider three possible hierarchical mechanisms that can put (legal) order to the relations between domestic and international tribunals. The first part of the article presents the analysis of the possibility to consider the judgments of international tribunals as binding precedents for domestic Courts. In the second part, the focus is on the establishment of a general duty for domestic tribunals to enforce the judgments of international Courts. The third one presents the study of the feasibility of a formal recognition of international tribunals' authority to carry out an appeal review of the decisions of domestic judicial organs. This work examines the hierarchy between domestic and international tribunals from a top-down approach with international tribunals, placed au sommet of a transnational judicial pyramid.

\section{International Judgments as Binding Precedents for National Courts}

What is the legal force of the dispositive part of the judgment of an international tribunal, i.e., the part that contains the motivation of the judgment, based on the interpretation and application of the relevant legal rules? Is this part of the judgment binding for domestic tribunals, or does it only possess "informational" value for national judges? Is the judgment of an international tribunal only a "fact" for domestic courts, or does it have inherent "normative" authority? All these questions essentially relate to the consideration of international judgments as binding precedents for national tribunals.

As mentioned above, there are no written or unwritten rules of domestic or international law on this subject. However, it is worth mentioning that there are such rules regarding the legal value of international judgments in international law. In fact, by virtue of many conventional norms, the judgments of international courts and tribunals are not a 
source of international law, and the stare decisis doctrine does not apply in the international legal order. ${ }^{56}$ Many international tribunals themselves have enounced that their jurisprudence is not a binding source of international law. ${ }^{57}$

In the lack of express legal rules regarding the consideration of international judgments as binding judicial precedents for national judges, the international tribunals and their domestic counterparts have adopted divergent and contradictory opinions on the subject. Most international tribunals have preferred to stay silent on this issue. Others have developed a jurisprudence that actually affirms that their judgments are binding sources of law for the tribunals of the States that have ratified their constitutive treaties. At the same time, some domestic tribunals have openly rejected the possibility for the judgments of international

56 In this sense, articles 38 and 59 of the Statute of the ICJ show that the judgments of this international tribunal do not create binding precedents for future cases. By virtue of article 38: " 1 . The Court, whose function is to decide in accordance with international law such disputes as are submitted to it, shall apply: a. international conventions, whether general or particular, establishing rules expressly recognized by the contesting states; b. international custom, as evidence of a general practice accepted as law; $c$. the general principles of law recognized by civilized nations; $d$. subject to the provisions of Article 59, judicial decisions and the teachings of the most highly qualified publicists of the various nations, as subsidiary means for the determination of rules of law. 2 . This provision shall not prejudice the power of the Court to decide a case ex aequo et bono, if the parties agree thereto." According to article 59: "The decision of the Court has no binding force except between the parties and in respect of that particular case." The articles contained in the treaties establishing other international tribunals usually do not include their previous decisions between the binding sources of international law that they are competent to apply. The only exception to that rule is article 21- 2 of the Statute of the International Criminal Court. By virtue of this provision: "The Court may apply principles and rules of law as interpreted in its previous decisions."

57 Thus, for example, the ICJ, in the Fisheries Jurisdiction case considered that the Court cannot adopt judgments sub specie legis ferendae. (ICJ, Fisheries Jurisdiction, United Kingdom v Iceland, Merits, Judgment, 25 July 1974, para 53). In the same sense, in its Consultative Opinion on the Legality of the Use Nuclear Weapons, the Court affirmed that it cannot create law through the adoption of binding precedents. (ICJ, Legality of the Threat or Use of Nuclear Weapons, Advisory Opinion, 8 July 1996, para 105). In the Kupreskic case, the ICTY stated that it cannot adhere to the stare decisis doctrine of Common Law countries and that the "judicial precedent is not a source of international criminal law". (ICTY, Kupreskic et. al., 14 January 2000, para 537). The ECHR has also found that it cannot create binding legal precedents in the fulfillment of its judicial function. (CEDH, Johnston and others $v$. Ireland, 18 December 1986, para 53). 
tribunals to create judicial precedents that would be binding for domestic courts. Yet, others have avowed that they consider international judgments as binding judicial precedents and sources of law.

The IACHR, in the Almonacid Arellano case, ${ }^{58}$ considered that its judicial interpretations of the Inter-American Convention on Human Rights are binding for domestic judges of the Convention's member States. The Court ruled that the conventionality control domestic judges have to carry out includes not only their obligation to exam the compatibility of domestic law with international human rights treaties but also their duty to scrutinize its conformity with the Court's jurisprudence. ${ }^{59}$ The same findings were confirmed in the Gelman case of the IACHR in the following terms: "By the fact that States are members of the InterAmerican Convention on Human Rights, all their organs, including the domestic judges should perform (...) a conventionality control (...), that takes into account (...) the precedents of the Inter- American Court". ${ }^{60}$ Without expressly admitting to doing so, the IACHR has affirmed that its decisions create binding precedents for domestic judges of the Inter-American Convention's member States. ${ }^{61}$ This means the American Convention, as a treaty, and its judicial interpretation and application by

58 According to the Court: "The Court is aware that domestic judges and courts are
bound to respect the rule of law, and therefore, they are bound to apply the provisions
in force within the legal system. However, when a State has ratified an international
treaty such as the American Convention, its judges, as part of the State, are also
bound by the Convention. This forces them to see that all the effects of the provi-
sions embodied in the Convention are not adversely affected by the enforcement of
laws which are contrary to its purpose and that have not had any legal effects since
their inception. In other words, the Judiciary must exercise a sort of "conventionality
control" between the domestic legal provisions which are applied to specific cases and
the American Convention on Human Rights. To perform this task, the Judiciary has to
take into account not only the treaty, but also the interpretation thereof made by the
Inter-American Court, which is the ultimate interpreter of the American Convention"
(IACHR, Almonacid-Arellano et al v. Chile, 26 September 2006 (Preliminary Objections,
Merits, Reparations and Costs) 59 Almonacid Arellano case, para 124

60 IACHR, Gelman Vs. Uruguay, 24 February 2011, 2006 (Preliminary Objections, Merits, Reparations and Costs), para 239.

61 Sergio Fuenzalida Bascuñán, "La jurisprudencia de la Corte Interamericana de Derechos Humanos como fuente de derecho. Una revisión de la doctrina del "examen de convencionalidad". Revista de Derecho (Valdivia), 28 no. 1 (2015): 171-192. http:// dx.doi.org/10.4067/S0718-09502015000100008 
an international tribunal have the same binding legal value for judges in the domestic legal order. ${ }^{62}$ Some authors have even suggested that the Courts' precedents can acquire a higher legal force, as the Court is the supreme and "ultimate interpreter" of the Convention. ${ }^{63}$ In fact, if States wish to do so, they can modify the treaty, but they may not modify the Court's interpretation of the judgments once they have acquired the status of res iudicata. All the judgments of the Court that interpret the Convention (i.e., all judgments) are binding for domestic tribunals, regardless if States have been or nor parties to the proceedings that originated the Courts' decisions.

To consider that the sentences of this international tribunal constitute binding judicial precedents for domestic judges of the Convention's member States amounts to establish vertical hierarchical relations between the IACHR and domestic courts. With great discretion, the IACHR is trying to place itself at the top of a hierarchically organized relationship with domestic judges. We know that in domestic judicial systems, the vertical precedent is the most commonly accepted. Only a higher court, in the hierarchy of domestic judicial systems, can create binding precedents for lower tribunals' future similar cases. The IACHR, in the Almonacid Arellano case, definitely is trying to "submit" to its superior authority all the domestic courts of the State members of the Inter-American Convention and to elevate itself to the category of a supra-national court in a hierarchically integrated Inter-American judicial system that will serve the ultimate objective of human rights protection. In the judges' vision, the conventionality control must convert domestic tribunals on "Inter-American" judges ${ }^{64}$ and, upon the guidance of the Court's jurisprudence binding character, all errors in the domestic judicial application and interpretation of the Convention can be avoided. In this sense, the IACHR has gone further than the ECHR. Although most member States of the European Convention of Human

62 Max Silva Abbot, "Control de convencionalidad interno y jueces locales: un planteamiento defectuoso". Estudios Constitucionales, 14 no. 2 (2016): 101-142. http://dx.doi. org/10.4067/S0718-52002016000200004

63 Fuenzalida, "La jurisprudencia de la Corte Interamericana de Derechos...".

64 "Interpretación conforme y control difuso de convencionalidad. El nuevo paradigma para el juez mexicano". In La reforma constitucional de derechos humanos. Un nuevo paradigma edited by Miguel Carbonell y Pedro Salazar, 339-349. Mexico: Universidad Nacional Autónoma de México, 2012. 
Rights spontaneously respect the European Court's precedents, the Court has never considered them as binding sources of law by its own authority. On the contrary, as mentioned before, the ECHR has expressly rejected its capacity to create law. ${ }^{65}$

When faced with the possibility to consider international judgments as binding judicial precedents and sources of law, the domestic tribunals have adopted divergent opinions. Some have indeed embraced the IACHR reasoning in the Almonacid Arellano case and have considered that the international tribunals' judgments can create binding precedents because they constitute binding interpretations (some kind of res interpretata) of international treaties - a binding source of law at domestic and international levels. Domestic judges, therefore, deduce the binding character of the international judgments from the binding nature of the international legal norm that international tribunals interpret and apply.

A NAFTA panel, constituted by virtue of chapter 19 of the agreement, explained this type of motivation. In a 2005 ruling, the panel considered binding the considerations of the WTO's Organ for Dispute Settlement in the Softwood Lumber case. According to the panel:

The United States has accepted, by virtue of the Memorandum for dispute settlement that its mechanism for dispute settlement serve "to clarify the existing provisions" of the WTO agreements (article 3-2 of the Memorandum). (...) The duties resulting from the Antidumping agreement of the WTO were clarified in the Softwood lumber case and this clarification was accepted by the United States. ${ }^{66}$

In a recent case, the Mexican Supreme Court recognized that the judgments of an international tribunal, particularly the IACHR, are binding precedents for all domestic judges. In the Court's opinion:

the Inter-American jurisprudence integrates itself in a system of precedents, where all the interpretative elements contained in a

\footnotetext{
65 CEDH, Johnston and others v. Ireland, 18 December 1986, para. 53.

66 ITLOS, United States-Investigation of the International Trade Commission in Softwood Lumber from Canada, Recourse by Article 25.1 of the DSU by Canada-Report by Panel, May 9, 2006; Re Matter of Certain Softwood Lumber Products from Canada (opinion and Order), NAFTA, Extraaordinary Challenge Committee, August, 10, 2005, p. 42-43.
} 
judgment, adopted by the IACHR have binding legal force (...). The jurisprudence of the IACHR is an "extension" of the American Convention on Human Rights. ${ }^{67}$

According to the Court, this binding force of the interpretative part of the judgments of the IACHR concerns all its case law, including cases where Mexico has not been part. ${ }^{68}$ Moreover, the Supreme Court retained the stare decisis doctrine regarding the judgments of the IACHR in the following terms: "the application of the rules developed by the IACHR in cases where Mexico was not part, should depend on (...) the analogy of the factual background and the particularity of the (domestic) case with the Inter-American precedent."

Many other member States of the Supreme Courts of the American Convention have arrived at the same conclusion. ${ }^{69}$ The Supreme Court of Costa Rica found that:

it should be noted that if the Inter-American Court of Human Rights is the natural organ to interpret the American Convention on Human Rights (...), the power of its decision when interpreting the Convention (...) shall have -in principle- the same value as the interpreted rule. ${ }^{70}$

Similarly, the Dominican Republic's Supreme Court of Justice found that:

consequently, the Dominican State and, therefore, Judiciary, are bound not only by the rules of the American Convention on Human Rights, but also by interpretations thereof made by the competent organs, created as means of protection, according to Article $33 .{ }^{71}$

\footnotetext{
67 Mexican Supreme Court of Justice, Contradicción de tesis 293/2011

68 Ibid.

69 IACHR, Cabrera Garcia y Montiel Flores Vs. México, 26 November 2010, parra. 226-232.

70 Constitutional Chamber of the Supreme Court of Justice of Costa Rica Constitutional Motion, Opinion 2313-95 (Case File 0421-S-90), 9 May 1995, Considering clause VII.

71 Supreme Court of Justice of the Dominican Republic, Resolution N 1920-2003, 13 November 2003.
} 
The Peru's Constitutional Court also ruled:

The binding nature of the judgments of the [Inter-American Court] does not end with the operative paragraphs (which, certainly, applies only to the State party to the proceeding), but it also extends to its grounds or ratio decidendi. (...) In fact, the Inter-American Court's powers to interpret and apply the Convention, enshrined in Article 62(3) of said treaty, together with the mandate of the CDFT of the Constitution, means that an interpretation of the provisions of the Convention issued in any proceeding is binding for all domestic governmental institutions, including, of course, this Court. ${ }^{72}$

The Argentina's Supreme Court of Justice acknowledged that the decisions of the Inter-American Court "are binding for the Argentine State (article 68(1), American Convention);" therefore, it was established that "in principle, the content of its decisions must be subordinated to the decisions of the international Court". ${ }^{73}$

All these rulings demonstrate the existence of a political will to consider the judgments of international tribunals as binding precedents for domestic judges. However, their legal reasoning is weak. The consideration of a judgment of an international tribunal, such as the IACHR as a binding precedent because it possesses some kind of res interpretata and is, thus, an "extension" of a binding international treaty is not a convincing legal argument, but a logical fallacy. The judicial interpretation of a legal norm cannot be considered binding because of the obligatory nature of the interpreted international norm. There is not just one way to interpret a norm and there are, as well, many possible interpreters of one. If we follow this reasoning, the interpretation of a treaty done by an international legal scholar, the lawyers of the party that brings a case based on a treaty before a national or international tribunal, and even the journalists' interpretation of a treaty may become binding as an

\footnotetext{
72 Constitutional Tribunal of Peru, (case file $\mathrm{N}^{\circ} 2730$ - 2006-PA/TC), 21 July 2006, Ground 12.

73 Supreme Court of Justice of the Republic of Argentina, Esposito, Miguel Angel s/ motion of statute of limitation of the criminal proceeding brought by bis defense, 23 December 2004, (Case file 224.XXXIX), Considering parra. 6.
} 
"extension" of a binding treaty. ${ }^{74}$ In the same sense, the interpretation of the Constitution of a State by its Supreme Court is not binding for lower courts because of the binding nature of the Constitution. Otherwise, all judicial interpretations of the supreme norm, even those developed by lower courts, would be binding as an "extension" of the Constitution. Vertical judicial precedents are binding because they come from a higher tribunal, who has the legal authority to settle binding interpretations for lower tribunals. The "extension" argument advanced by the Mexican Supreme Court and all the other Supreme Courts of Latin American states, and the "authoritative and ultimate interpretation" reasoning developed by the IACHR, seeks to distract the public attention from what is really at stake: the acceptance of an international tribunal's judgments as a vertical judicial precedent, emanated from a higher supranational court, and the fact that they are binding for lower domestic courts.

Other national courts have understood this clearly and, therefore, have denied to international judgments the authority of binding vertical precedents for domestic Courts. The us Supreme Court, in the Sánchez Llamas case $^{75}$ considered that the ICJ judgments deserved "respectful consideration", but were not binding for the country's Courts. ${ }^{76}$ The Court insisted on the fact that the us Constitution grants the ultimate authority to interpret international treaties to the Us domestic judicial bodies. ${ }^{77}$ In the Supreme Court's opinion, nothing in the structure of the ICJ or its objectives suggested that its interpretations should be considered as binding precedents for domestic tribunals. ${ }^{78}$

Even so, the fact that some international and domestic tribunals, such as the IACHR and the Supreme Courts of many Latin American countries have established that the judgments of international tribunals

\footnotetext{
74 Moreover, the interpretation of international treaties done by domestic tribunals will also become binding for other national and international tribunals, only because they interpret and apply a binding treaty. In domestic legal systems, the binding character of judicial precedents is not "tied" to the obligatory nature of the legal norms that tribunals interpret or apply. In such a case, absolutely all the precedents of all domestic courts, either higher or lower, in the judicial hierarchy will be binding for all other tribunals, as they always interpret and apply binding sources of domestic law.

75 US Supreme Court, Sanchez-Llamas v. Oregon, 548 U.S. 331 (2006).

76 Sánchez-Llamas, parra. 2677-2678.

77 Sánchez-Llamas, parra. 2684.

78 Sánchez-Llamas, parra. 2684.
} 
can be regarded as binding precedents for domestic courts, shows that it is possible to organize the relationship between them on hierarchical grounds. The consideration of international judgments as binding precedents for domestic tribunals gives international courts a higher hierarchical position in a vertically organized transnational judicial system.

The benefits of establishing international judgments as vertical judicial precedents for domestic courts are clear. By so doing, international tribunals will become the ultimate interpreters of international law because of their high-level expertise in this field. Their better knowledge of the sources of international law would give them authority to appreciate the legality of all State acts regarding international law. If we suppose that international courts have more apt legal reasoning in international law, then they are more able to arrive to better answers than domestic courts. ${ }^{79}$ The precedential value of their judgments would permit them to settle the correct and more skillful interpretation of international norms and principles, and, therefore, avoid judicial errors made in the process by the decisions of domestic courts. As higher courts, international tribunals can assure uniformity and consistency in the interpretation and application of international law by domestic judges all around the world. This will ensure some kind of "systemic integration" between domestic and international judicial bodies in the application and interpretation of international law. As Jean D'Apresmont shows, systemic integration is enriched in the article 31.3 of the Vienna Convention on the Law of Treaties

and is premised on the fiction that, despite international lawmaking being fragmented and decentralized, any new rule has been made with the awareness of other existing rules. In that sense, the principle of systemic integration presupposes the formal unity of the legal system.

In D'Aspremont's view, "that means that when several norms bear on a single issue, they should, to the greatest extent possible be

79 Evan Caminker, "Why Must Inferior Courts Obey Superior Court Precedents?". Stanford Law Review, 46 no. 4 (1994): 845. https://doi.org. 10.2307/1229094 
interpreted so as to give rise to a single set of compatible obligations". ${ }^{80}$ The precedential value of the judgments of international tribunals for domestic courts will have exactly the same result: the preservation of the unity in the interpretation and application of international law at the international and domestic levels, by a hierarchically ordered system of international and domestic judicial bodies, both at the service of justice and international law.

The precedential value of international judgments for domestic courts will also ensure equal treatment before the law of international law's subjects. The uniformity in the interpretation and application of international law by domestic and international tribunals will guarantee that they will "treat similarly situated litigants equally". As a result, there will be greater fairness in the administration of justice, based on international law, and there will not be more geographical and domestic variations in the judicial life of the otherwise uniform norms of international law. ${ }^{81}$

\section{Domestic Tribunals as Enforcers of International Courts' Judgments}

State's obligation to enforce the judgments of international tribunals is a normal consequence of the acceptance of those tribunals' jurisdictions and the ratification of their constitutive treaties. ${ }^{82}$ The duty of states to comply with the decisions of international tribunals also arises by

80 Jean D'Aspremont, “The Systemic Integration of International Law by Domestic Courts: Domestic Judges as Architects of the Consistency of the International Legal Order". In The Practice of International and National Courts and the (De-) Fragmentation of International Law, edited by Ole Kristian Fauchald and André Nollkaemper, 141-165. Oxford: Hart Publishing, 2012.

81 Caminker, "Why Must Inferior Courts Obey Superior...”, 852.

82 For example, according to article 94 of the UN Charter: "Each Member of the United Nations undertakes to comply with the decision of the International Court of Justice in any case to which it is a party. If any party to a case fails to perform the obligations incumbent upon it under a judgment rendered by the Court, the other party may have recourse to the Security Council, which may, if it deems necessary, make recommendations or decide upon measures to be taken to give effect to the judgment." 
virtue of two general principles of domestic and international law: res indicata ${ }^{83}$ and bona fides. ${ }^{84}$

The compliance obligation on behalf of States does not concern all the parts of the judgment of an international tribunal, but only the one that established some type of duties to act or to refrain from action for States' authorities. Traditionally, a distinction is made between the reasoning part of the judgment of an international tribunal and its operative part. ${ }^{85}$ By virtue of the principle of res indicata, only the dispositif of an international judgment is binding for parties of the dispute, as only this part of the judgment creates direct obligations on their behalf. As stated by the PCIJ in its Consultative Opinion on Dantzig Postal Services: "the reasoning contained in a judgment, beyond its operative part, does not possess a binding legal force". ${ }^{86}$ In the same sense, as mentioned by Judge Anzilotti in the Chorzow Fabric case, "the binding character of a judgment only appl[ies] to the operative part (le dispositif) and not to the exposition of motifs (les considérants)".

83 The res indicata principle is originated in Roman law's maxims Interest reipublicae ut sit finis litium (The public interest implies to put an end to a litigation) and Nemo debet bis vexari pro una et eadem causa (No one should act twice for the defense of the same cause). By virtue of this principle judicial decisions (and arbitral awards, as well) are definitive and binding for the parties and they should enforce them in good faith. This principle is inherent to the essence of the judicial settlement of disputes: if judgments were not binding to the parties, their judicial resolution would not be possible. The res iudicata principle has "crystalized" in the constitutive statutes of all the international tribunals. Thus, for example, according to article 59 of the Statute of the ICJ: "The decision of the Court has no binding force except between the parties and in respect of that particular case." By virtue of article 33 of the ITLOS Statute: "1. The decision of the Tribunal is final and shall be complied with by all the parties to the dispute."

84 One of the corollary of the principle of good faith in treaty law (and contract law, in general) is the maxim pacta sunt servanda, i.e. the obligation of States to comply with the provisions of international treaties. As the jurisdiction of international tribunals relies on the ratification of an international treaty, the duty of the State to comply with their judgments also derives from the pacta sunt servanda principle.

85 In the reasoning part, judges apply and interpret the relevant law to the facts of the particular case brought to their jurisdiction. This part exposes the "motifs" for the judgment issued at the end of the judicial process, while its operative part makes a binding conclusion upon the existence or inexistence of violations of the applicable legal norms and the consequences attached to this determination for the parties to the dispute.

86 PCIJ, Polish Postal Service in Dan₹ig, Advisory Opinion, 16 May 1025, pp. 29-30. 
Secondly, the operative part of the judgment is, in principle, binding for the State, as a whole, and does not have as addressee one of its domestic organs or agents. ${ }^{87}$ Traditionally, international courts have given states the possibility of choosing the specific means to comply with an international judgment and to designate, by its authority, the organs or agents that have to carry out the compliance measures. It is clear that only specific State organs can enforce some duties deriving from the compliance with the judgment of an international tribunal. ${ }^{88}$ However, recent years are presenting a new phenomenon: international tribunals' judgments, whose operative part is directly addressed to the members of the domestic judiciaries of the states' parties to the dispute. Many international courts have indeed "pierced the unitary veil" of the State ${ }^{89}$ and have created, in their sentences, direct enforcement duties for the domestic judicial power.

Domestic tribunals are traditionally acting as enforcers of foreign tribunals' judgments in the field of judicial cooperation in private international law. Domestic judges are also competent to grant the exequatur and order the enforcement of international arbitral awards. However, this type of enforcement is different as it only consists of giving imperium and full effects to the content about a foreign judgment or arbitral award in the domestic legal order.

${ }^{87}$ Alexandra Huneeus, "Courts resisting Courts: Lessons from the Inter-American Court's struggle to enforce Human Rights", Cornell International Law Journal, 44 no. 3 (2011): 493-533. https://scholarship.law.cornell.edu/cilj/vol44/iss3/2

88 Thus, for example, if an international court finds that an internal legislation is not compatible with the international law commitments of the State and orders, in the operative part of its judgment, to put an end to this violation, the only State organ capable to modify or abrogate the legislation will be State's legislative power. (André Nollkaemper, "Conversations Among Courts, Domestic and International Adjudicators." In The Oxford Handbook of International Adjudication, edited by Cesare Romare, Karen Alter and Yuval Shany. (Oxford University Press, 2015). 10.1093/law/9780199660681.003.0024. If an international tribunal considers that a State act has violated the human rights of an individual and orders to the State to make a public statement of recognition of that violation, the only organ that can comply with that obligation will be State's executive power.

89 Andrea Gattini, "Domestic Judicial Compliance with International Judicial Decisions: Some Paradoxes." From Bilateralism to Community Interest: Essays in Honour of Bruno Simma, edited by Ulrich Fastenrath, Rudolf Geiger, Daniel-Erasmus Khan, Andreas Paulus, Sabine von Schorlemer, and Christoph Vedder, 1168-1188. (Oxford University Press, 2011), 1175. 
International tribunals have been more active in this sense and have tried to convert domestic tribunals to an "enforcement agency" for their own decisions. This evolution is particularly visible in the ICJ case law. During the first years of its functioning, the ICJ was particularly cautious regarding the margin of appreciation left to States in order to enforce the operative part of its judgments. An example of extreme caution was the dispositif of its ruling in the Asylum case. ${ }^{90}$ In fact, in that case, the Court did not order any specific measures of enforcement; it just indicated that Colombia had to put an end to the asylum unlawfully granted to Víctor Raúl Haya de la Torre. The uncertainty caused by this omission of the Court was of such a dimension that justified the initiation of a second proceeding on that same question in the Haya de la Torre case. ${ }^{91}$ However, at the end of the twentieth century, the Court radically changed its position and started to appoint domestic judges as organs for the enforcement of its judgments.

Thus, in the Cumaraswamy case, ${ }^{92}$ the ICJ addressed itself to the Malaysian Government but ordered the domestic judges to recognize the jurisdictional immunity of a Malaysian citizen, based upon its quality of being a UN agent and putting an end to any judicial suit against him. Later, in the 2001 LaGrand case, ${ }^{93}$ the Court considered that the us had the obligation to re-exam the judicial proceedings that led to the pronunciation of a death penalty against two German nationals. The Court ordered the re-opening of the files because of the existing violation of their right to information on consular assistance, granted by article 36 of the Vienna Convention on Consular Relations. The only organs that could enforce this part of the judgment were the Us' domestic judges. One year before, in the Mandat d'arrêt case, ${ }^{94}$ the Court addressed itself to the Belgian Government but requested the suspension of an arrest warrant issued against an ex-President of the Democratic Republic of

\footnotetext{
90 ICJ, Asylum, Colombia v Peru, Merits, Judgment, 20 November 1950.

91 ICJ, Haya de la Torre Case, Colombia v Peru, Merits, 13th June 1951.

92 ICJ, Difference Relating to Immunity from Legal Process of a Special Rapporteur of the Commission on Human Rights, (Advisory Opinion), 29th April 1999.

93 ICJ, LaGrand, Germany v United States, Judgment, Jurisdiction, Admissibility, Merits, 27th June 2001.

94 ICJ, Case Concerning the Arrest Warrant of 11 April 2000 (Democratic Republic of Congo v Belgium) Judgment, Merits, Preliminary Objections, 14th February 2002, para 78.
} 
Congo. Therefore, the real addressees of this obligation were the members of the Belgian domestic Judiciary. ${ }^{95}$ In 2002, in the interesting case Certain Criminal Proceedings in France, Congo instituted proceedings against France seeking the annulation of judicial measures adopted by French tribunals against Congolese nationals, in the exercise of domestic tribunals' universal jurisdiction for acts of torture and crimes against humanity. The Court dismissed the case because Congo suspended its demand, and, in 2010, the Court suppressed the case from the list of pending cases. ${ }^{96}$ In the Jurisdiction and Enforcement of Judgments in Civil and Commercial Matters case, ${ }^{97}$ the Court examined the legality of the negative of a Belgian tribunal to enforce judgments against a Belgian company, issued by Swiss tribunals, according to the applicable rules to a private international firm. Finally, this case was also dismissed. ${ }^{98}$ Very similar were the outcomes of the case Questions Relating to the Obligation to Prosecute or Extradite. ${ }^{99}$ However, the fact that these cases were brought to the jurisdiction of the Court shows that States can consider the ICJ as a forum that can order to domestic judges to re-open trials and to suspend internal judicial proceedings because of violations of international law.

In the same sense, in the 2004 Avena case, ${ }^{100}$ the ICJ found that the "appropriate reparation" consisted "in the obligation of the United States of America to provide, by means of its own choosing, review and reconsideration of the convictions and sentences of the Mexican nationals (...)". ${ }^{101}$ However, it was clear that the only "means" to achieve the

95 Gattini., “Domestic Judicial Compliance with International Judicial...”, 1175.

96 ICJ, Certain Criminal Proceedings in France (Republic of the Congo v. France). Overview of the case, https://www.icj-cij.org/en/case/129

97 ICJ, Jurisdiction and Enforcement of Judgments in Civil and Commercial Matters (Belgium v. Switzerland), Overview of the Case, https://www.icj-cij.org/en/case/145

98 ICJ, Jurisdiction and Enforcement of Judgments in Civil and Commercial Matters (Belgium v. Switzerland), Overview of the Case, https://www.icj-cij.org/en/case/145

Stephanie De Dycker, "Private International Law Disputes Before the International Court of Justice.” Journal of International Dispute Settlement, 1 no. 2 (2010): 475-498. https:// doi.org/10.1093/jnlids/idq006

99 ICJ, Questions relating to the Obligation to Prosecute or Extradite (Belgium v. Senegal), Overview of the Case, https://www.icj-cij.org/en/case/144

100 ICJ, Case concerning Avena and Other Mexican Nationals, (Mexico vs. United States of America), Merits, 31 March 2004.

101 ICJ, Avena, p. 75. 
review and reconsideration of the sentences were judicial, and the real addressees of the obligation to enforce the ICJ judgment were the US tribunals. Finally, in 2013, in the Jurisdictional Immunities of the State case, the ICJ adopted a very intrusive attitude toward the duty of domestic judges to respect and enforce its decisions. In the operative part of the judgment, the Court founded that "the Italian Republic must, by enacting appropriate legislation, or by resorting to other methods of its choosing, ensure that the decisions of its courts and those of other judicial authorities infringing the immunity which the Federal Republic of Germany enjoys under international law cease to have effect". ${ }^{102}$ In other words, the ICJ ordered to Italy the annulation of a judicial decision rendered by the highest tribunal in its internal judicial hierarchy. Therefore, the Italian legislator adopted an internal law on January 14th, 2013, concerning Italy's adherence to the UN Convention on the State's Immunities. Its fourth article, titled Compliance with ICJ Judgments, stated that the ICJ judgments established the lack of jurisdiction of Italian courts in cases concerning public acts of foreign States; consequently, any decision that is not consistent with the ICJ's judgments can be subject to a review for lack of jurisdiction. ${ }^{103}$

The IACHR has also been very pro-active in addressing directly the members of the national judiciaries in the operative part of its judgments. Articles 67 and 68 of the Inter-American Convention on Human Rights establish the duty of States to comply with the Court's judgments. ${ }^{104}$ Since the adoption of its Consultative Opinion on the International Responsibility for Adoption and Application of Laws Contrary to

\footnotetext{
102 ICJ, Jurisdictional Immunities of the State, p. 60.

103 ICJ, Jurisdictional Immunities of the State (Germany v. Italy: Greece intervening), Overview of the Case https://www.icj-cij.org/en/case/143; Almeida, Paula Wojcikiewicz. "Jurisdictional Immunities of the State (Germany v. Italy): The International Court of Justice against the Evolution of International Law, “ ACDI 11 (2018): 21. http://www. anuariocdi.org/anuario2018/01RevACDI_11_PWojcikiewicz.pdf

104 By virtue of article 67: "The judgment of the Court shall be final and not subject to appeal. In case of disagreement as to the meaning or scope of the judgment, the Court shall interpret it at the request of any of the parties, provided the request is made within ninety days from the date of notification of the judgment." According to article 68: "1. The States Parties to the Convention undertake to comply with the judgment of the Court in any case to which they are parties. 2. That part of a judgment that stipulates compensatory damages may be executed in the country concerned in accordance with domestic procedure governing the execution of judgments against the State."
} 
the Convention, ${ }^{105}$ the Court considered that the obligation to comply with its judgments derives from a basic principle of international law, which is recognized in the international jurisprudence and in article 27 of the Vienna Convention on the Law of Treaties. According to this principle, States have to fulfill their international obligations in good faith (pacta sunt servanda) and cannot invoke their internal laws as a justification for the non-observance of their international commitments. Even if in the Ivcher Brontstein case, ${ }^{106}$ the IACHR considered that this conventional obligation is binding for the State as a whole and for all of its domestic organs, in its more recent case law, the Court has addressed itself directly to national judges. As Huneeus ${ }^{107}$ shows, "of the 114 contentious cases in which the Inter-American Court issued remedies, from its first case in 1979 to December 2009, it issued equitable orders that require action by a national judiciary in 78 ". From these 78 cases, 52 were cases where the Court asked for a (new or renewed) criminal investigation, in five cases, the Court ordered new due process safeguards to be included in domestic judicial proceedings, and, in three other cases, the Court expressly requested the nullification of a domestic tribunal's judgment. ${ }^{108}$ Thus, for example, in the Castillo Petru₹zi case the Court found that

the proceedings conducted against Mr. Jaime Francisco Sebastián Castillo Petruzzi (...) are invalid, as they were incompatible with the American Convention on Human Rights, and so orders that the persons in question be guaranteed a new trial in which the guarantees of due process of law are ensured. ${ }^{109}$

\footnotetext{
105 IACHR, Responsabilidad internacional por expedición y aplicación de leyes violatorias de la Convención (arts. 1 y 2 Convención Americana sobre Derechos Humanos), Consultative Opinion OC-14/94, 9 December 1994, parra 35.

106 IACHR, Ivcher Bronstein vs. Perú, 24 September 1999, para 37, IACHR.

107 Huneeus, “Courts resisting Courts: Lessons from the Inter-American...”, 502.

108 Ibid.

109 IAChr, Castillo-Petruzzi et al. v. Peru, (ser. C) No. 52, 226(13), 30 May 1999.
} 
In the Aptiz Barbera case ${ }^{110}$, the Court ordered Venezuelan's Judiciary to re-install three judges in their office. ${ }^{111}$ Moreover, in the Cotton Field case, the Court ordered Mexican judges to take capacitation courses on gender equality and women's human rights. ${ }^{112}$ In the Raxcaco Reyes case, the Court requested Guatemalan judges not to apply the death penalty imposed to the claimant in a previous sentence and to pronounce a new indictment that cannot be, in any case, another death penalty. ${ }^{113}$

These few examples demonstrate that international tribunals are progressively considering domestic judges as direct addressees of the duty to enforce their sentences, and also show that international tribunals are acting more intrusively in the domestic judges' sphere of jurisdiction. Domestic judges never appear at the proceedings before the international tribunals and never sit at the "accused dock" in their respective courtrooms. However, by creating binding duties for them in the operative part of their decisions, the international courts are actually "judging domestic judges" and are "telling them directly what to do". The "power cession" that this involves relies on the acceptance of domestic judges to "follow orders" given to them by international tribunals. For some domestic tribunals, especially higher Courts in domestic judicial systems' hierarchy, "following orders" from international tribunals means to renounce to their position of "ultimate arbiter" the domestic legal order.

This situation gives path to a hierarchical type of relation between domestic and international tribunals, with the latter enjoying judicial power over their domestic counterparts. As stated above, international tribunals have asked their national colleagues to re-open proceedings

\footnotetext{
110 IACHr, Aptiz Barbera et al. vs. Venezuela, 5 August 2008, (Preliminary Objection, Merits, Reparations and Costs)

111 The Court expressed this obligation in the following terms: "the State must reinstate Juan Carlos Apitz Barbera, Perkins Rocha Contreras, and Ana María Ruggeri Cova, if they so desire, in a position in the Judiciary in which they have the same salaries, related benefits, and equivalent rank as they had prior to their removal from office." (IACHR, Aptiz Barbera, p. 71)

112 IACHr, González et al. ("Cotton Field") v. Mexico, 16 November 2009 (Preliminary Objection, Merits, Reparations, and Costs), parra 543.

113 IACHR, Raxcacó Reyes v Guatemala, 15th September 2005, (Merits, Reparations and costs), para 133

114 Ahdieh, "Between Dialogue and Decree..., 2029.
} 
or to carry out new proceedings, to re-place members of the domestic judiciaries in their offices, to suspend arrest warrants, to motivate their decisions, and, more drastically, to nullify domestic judgments that have already constituted res iudicata in the domestic legal order. This judicial "boldness" would not be possible if international tribunals were not seeing themselves as hierarchically superior to domestic courts. In fact, in national legal systems, only a higher court can issue orders binding and indicating lower tribunals how to treat future cases or how to improve their judicial skills. Only a superior court can order particular remedial actions to inferior tribunals, and only a higher judicial organ can order the nullification of the decision of a lower one. Some domestic courts have resented their consideration as (lower) enforcers of (higher) international courts' decisions and have shown their resistance to act as "subordinates" of international tribunals. These resistance techniques show a political will to "disobey" international judges' orders.

The most prominent example of the resistance of a domestic court to the duty to enforce the decision of an international tribunal is the second judgment of the Italian Supreme Court in the Ferrini saga. In a decision rendered in 2014, the Italian Supreme Court found that the judgment of the ICJ in the Jurisdictional Immunities of the State case could not enter the Italian legal order, by virtue of article 10 of the Italian Constitution and, thus, could not produce binding legal effects in that domestic system. Consequently, the Court declared that the Italian domestic law that incorporated the operative part of the ICJ judgment was invalid and nullified. The Court emphasized that in the international legal order, the interpretations contained in the judgments of the ICJ are definitive and that, in the relations between States, those judgments were not subject to any review by States' governments or internal judicial organs. However, according to the Court, this should not be the situation in States' domestic legal orders. ${ }^{115}$ If those judgments reveal to be contrary to fundamental constitutional principles of the State, its domestic judges should preserve the "inviolability" of these principles or, at least, "minimize their sacrifices". Some authors have seen in this position the development, by the Italian court, of a constitutional counter-limits doctrine to the obligation to enforce the

115 Italian Constitutional Court, Case No. 238, 22 October 2014. 
judgments of international tribunals in the domestic legal orders. ${ }^{116}$ It also demonstrates a political will to manifest loudly that domestic courts are not hierarchically subordinated to the ICJ and that some of them will no cede to the World Court the power to impose to them the duty to comply with judgments that contradict fundamental principles of the internal legality they have to protect and enforce. The Italian Court actually considered itself on a hierarchically higher level than the ICJ regarding the domestic legal order. As "ultimate arbiter" of the domestic legality, this national Court submitted the ICJ's judgment to a constitutionality control. The message is clear: the ICJ might be a higher court in the relations between States, but it's not hierarchically superior to domestic tribunals as in the last resort, they don not pertain to the international but to the domestic legal order.

Other domestic tribunals that have disobeyed their duty to enforce the dispositive part of an international tribunal's judgment developed similar reasoning. The Venezuelan Supreme Court refused to submit itself to the IACHR order in the Aptiz Barbera case, as it violated the res indicata of a previous judgment of this domestic tribunal. More generally, the Court stated that it could only enforce the IACHR's decisions if they respect "the sovereignty" of Venezuela. ${ }^{117}$ In the Medellin case, ${ }^{118}$ the us Supreme Court considered that the domestic tribunals of that country are not obliged to obey the ICJ's judgments and that these judgments were not binding unless properly incorporated in the domestic law.

Even when domestic courts have accepted to become enforcers of the judgments of international tribunals, some of their judges have expressed resistance to the hierarchy implied in this type of relationship. In 2011, the Plenary of the Mexican Supreme Court recognized the obligation of Mexican judges to enforce the IACHR decision in the Radilla case. ${ }^{119}$ In that case, the Court ordered the members of the Mexican Judiciary to initiate criminal proceedings against the persons responsible for the forced disappearance of Mr. Radilla, to participate in training

\footnotetext{
116 Maria Palombino Fulvio, "Compliance with International Judgments: Between Supremacy of International Law and National Fundamental Principles." ZAÖRV, 75 (2015): 506. https://www.zaoerv.de/75_2015/75_2015_3_a_503_530.pdf

117 Supreme Court of Venezuela, Decision No. 1939, 18 December 2008.

118 US Supreme Court, Medellin v. Texas, 552 U.S. 491 (2008).

119 Mexican Supreme Court, Radilla, “Varios” 912/2010, 12 July 2011.
} 
programs on forced disappearance, and to study the Inter-American Jurisprudence on related issues. ${ }^{120}$ The majority of the Supreme Court considered that Mexican tribunals, including the Supreme Court as the highest constitutional tribunal, "cannot question the jurisdiction of the IACHR or evaluate the dispute, but only limit themselves to the enforcement of the part of the judgment that is addressed to them". ${ }^{121}$ In the opinion of the Court, the "resolution adopted by the IACHR is binding for all States organs (...), as the State has been party to the dispute. Therefore, for the Judicial Power, the sentence is binding not only in its operative part", but in its totality. ${ }^{122}$ In response to the decision of the majority, one of the dissenting judges indicated the hierarchical implications of these findings. He considered that the domestic judiciary should not enforce the requested measures, as they exceeded the reparation powers of the IACHR. He found that, if the Court was to allow the enforcement of the IACHR judgments by the domestic judiciary, the Inter-American Court would be able to "determine, by its own authority (...), all the academic activities" of domestic judges and the limits of the jurisdictional interpretation and application power of the "Highest Tribunal of the Republic", and that "Then, this international tribunal will become a Supreme Authority that decides the Public Policy of the Mexican State, beyond the National Institutions, derived from the popular will, (...). Nothing and no one should be beyond the Constitution". ${ }^{123}$

This opinion resumes the mindset of many domestic judges when it comes to cede power and accept obedience to international tribunals' orders to comply with the operative part of their judgments. To see domestic judges as enforcers of international judgments is to consider them as subaltern organs to the authority of international tribunals. Even if this can threaten some domestic judges' "egocentrism" and "sovereignism", the establishment of vertical cooperation between domestic and international tribunals can benefit the efficacy and uniformity in

\footnotetext{
120 IACHR, Radilla-Pacheco v. Mexico, 23 November 2009 (Preliminary Objections, Merits, Reparations, and Costs), Resolution point 10 and Considerant 32.

121 Mexican Supreme Court, Radilla Varios, para 19.

122 Ibid.

123 Particular vote of Judge Luis Maria Aguilar Morales regarding the judgment of the Plenary of the Mexican Supreme Court in the Case Varios 912/2010, http://dof.gob. $\mathrm{mx} /$ nota_detalle.php?codigo $=5212527 \&$ fecha $=04 / 10 / 2011$
} 
the application of the international law commitments of States at the domestic level.

If domestic or international law — through constitutional or treaty amendments - creates a general duty for domestic judges to enforce the sentences of international tribunals as higher hierarchical Courts, international judges would count with the unconditional help of their domestic counterparts to strengthen the respect for the international rule of law. In general, if there were duties for domestic tribunals to enforce the decisions of their international colleagues, there would be a substantial integration of both judicial bodies toward the promotion of uniform international standards for justice globally. Domestic judges are, in fact, the best placed to become the "compliance partners" of international courts, regarding the enforcement of their decisions. In this sense, George Scelle's theory of dedoublement fonctionnel would become particularly accurate, ${ }^{124}$ and domestic courts would fulfill a double function: enforcers of the international law commitments of their States and enforcers of the judgments of the international tribunals within the domestic legal order. Such a "partnership" would not only enhance compliance with international law in a broad sense but could also improve states' local judicial systems. ${ }^{125}$

\section{International Tribunals as Appellate Courts of Domestic Judges' Decisions}

International judges usually insist on the fact that they are not appellate tribunals of the judgments of domestic courts. However, many recent

\footnotetext{
124 The theory of dédoublement fonctionnel endorses the presumption that in every legal system there are three basic functions: legislative, executive and judicial. In domestic legal systems, State's organs, the so-called executive, legislative and judicial powers, fulfill these functions. The problem arises in the international legal system, as it lacks a central executive, legislative and judicial power, which would act in the name of the international community as a whole. Scelle's response to this inherent failure of international law was to argue that national organs and agents of the executive, legislative and judicial powers of each State should perform a double function. They were to act as organs and agents of their own State within its internal legal order and, at the same time, as agents and organs of international law. Antonio Cassese, Remarks on Scelle's Theory of "Role Splitting" (dédoublement fonctionnel) in International Law, 1 EJIL, 1990, 212.

125 Huneeus, “Courts resisting Courts: Lessons from the Inter-American...”, 531.
} 
cases show that, when faced with the appreciation of domestic judges' decisions conformity with international law, international tribunals do engage in some type of judicial review.

To appeal is to "apply to a higher court for a reversal of the decision of a lower court." 126 In domestic legal systems, the Court of Appeal will review the interpretation and application adopted by a lower court of a particular body of domestic law. It will examine the existence of judicial errors of fact and law in this process and, if necessary, corrects them by reversing the decision of the lower court. The decision of the appellate higher court is always binding for the lower tribunals. In a judicial system, when admitting appeals, the appellate courts are hierarchically superior to the judicial bodies subject to their review. In other words, the hierarchy between tribunals always defines the appellate review system. ${ }^{127}$ As other hierarchical tools for the regulation of the relations between different tribunals, the appeal serves two main objectives: correct errors and promote legal consistency both within and across tribunals. By so doing, the appeal enhances the legitimacy and the confidence of legal actors in the correct operation of a judicial system as a whole. ${ }^{128}$

It is clear that the appellate court should have jurisdiction to apply and interpret the same body of legal rules applied in the lower court's judgment. Traditionally, it was impossible to consider international tribunals as appellate courts of domestic judges' sentences, as both judicial bodies normally applied and interpreted different set of legal rules: national tribunals ruled over domestic law issues, and international tribunals, alone, had jurisdiction to resolve disputes based in international law. However, as mentioned before, nowadays, domestic judges fulfill an international judicial function and progressively use international law norms of different natures for settling disputes presented to their forum. ${ }^{129}$ Secondly, there are several cases where international tribunals

\footnotetext{
126 Definition of Appeal, https://en.oxforddictionaries.com/definition/appeal

127 Tsanakopoulos, "Domestic Courts in International Law...", 137.

128 Ahdieh, "Between Dialogue and Decree...", 2047.

129 What kind of international legal norms and principles can be invoked in domestic proceedings before national courts and tribunals? It is possible to classify these norms and principles according to the quality of their subjects in three categories: horizontal, vertical and transnational legal rules. The horizontal rules apply to relations between the primary subjects of international law: States and international intergovernmental
} 
can exam a case that has been subject previously to the jurisdiction of domestic courts. The principle res indicata is not applicable in the relationship between domestic and international tribunals. Consequently, international courts can actually review the compatibility of domestic courts' judgments with international law. ${ }^{130}$ That is particularly true in cases where the exhaustion of local remedies is required by international law itself. In the human rights field, for example, both the IACHR and the ECHR only allow cases to be brought to their jurisdiction if the plaintiffs have first litigated them before all the competent domestic judicial bodies. Both international tribunals decide cases that have supposed previous domestic judges' rulings, based on the application and interpretation of international law. Thus, the hearing of a case by those international courts, per se, implies that national tribunals "got

organizations. The vertical type of international legal norms is relevant to the relations between states and/or intergovernmental organizations and no State actors (individuals, private companies, No Governmental Organizations (NGOs), etc.). Finally, the transnational norms concern the interactions between private persons, exclusively. In principle, parties will not invoke the horizontal norms of international law in internal judicial proceedings, as their subjects (States and international intergovernmental organizations) have a special legal status regarding the jurisdiction of domestic courts and tribunals. In fact, both legal entities enjoy an immunity from jurisdiction for acts performed in their public functions. The main ground for the performance of an international judicial function by domestic judges remains the application and interpretation of vertical and transnational types of norms. One of the "revolutions" of contemporary international law is the recognition of the international legal personality of private persons. Many conventional and customary rules of international law create direct rights and duties upon private persons and establish their access to international mechanisms of dispute settlement. Even the customary rule of exhaustion of local remedies shows that, for international law, the "natural judge" of individuals and private companies is still their domestic judge. The transnational rules are another strong "point of connection" between domestic judges and international law. Nowadays, States member of the global Community have adopted many international multilateral conventions, whose principal objective is to develop uniform conflict rules of private international law and achieve harmonization of substantive rules in many fields of the transnational private relations (such as civil and family law, trade law, administrative and procedural law). By applying these important treaties of private international law and resolving disputes between private parties, that are subjects of more than one national legal system, domestic judges are frequently behaving as prima facie "private international law judges". (David Sloss and Michael Van Alstine, International Law in Domestic Courts. (2015), 7. http://digitalcommons.law.scu.edu/facpubs/889

130 Nollkaemper, "Conversations Among Courts...", 317. 
it wrong". ${ }^{131}$ In other cases, although the exhaustion of local remedies does not apply, international tribunals can act as de facto second judicial review organs (a second degree of the jurisdiction) of the application and interpretation of the same international law rules. Nowadays, international courts have to deal with questions of law previously adjudicated by national courts in an almost routine way.

In the LaGrand case, the ICJ considered that it could not act as an appeal court for domestic judgments. According to the Court:

Although Germany deals extensively with the practice of American courts as it bears on the application of the Convention, [its submissions] seek to require the Court to do no more than apply the relevant rules of international law to the issues in dispute between the Parties to this case. The exercise of this function, expressly mandated by Article 38 of its Statute does not convert this Court into a court of appeal of national criminal proceedings. ${ }^{132}$

However, few years later, in the Avena case, the ICJ hold that:

If and so far as the Court may find that the obligations accepted by the parties to the Vienna Convention included commitments as to the conduct of their municipal courts in relation to the nationals of other parties, then in order to ascertain whether there have been breaches of the Convention, the Court must be able to examine the actions of those courts in the light of international law. The Court is unable to uphold the contention of the United States that, as a matter of jurisdiction, it is debarred from enquiring into the conduct of criminal proceedings in United States courts. ${ }^{133}$

There are several examples of international tribunals acting as de facto appellate tribunals for domestic courts' decisions. Traces of such experiences can be found at the very beginning of the development of mechanisms for dispute settlement in international law. In fact, with the adoption of the Jay Treaty between the Us and Great Britain, some

\footnotetext{
131 Huneeus, “Courts resisting Courts: Lessons from the Inter-American...”, 514.

132 ICJ, LaGrand, parra 52.

133 ICJ, Avena, parras. 528, 597- 598.
} 
international arbitral commissions received the power to review the judgments of domestic tribunals. An international arbitral tribunal constituted according to the provisions of that treaty had the opportunity to review and reverse some of the findings of the Us Supreme Court in its Prizes Case. ${ }^{134}$ In the Loewen Group, Inc. v. United States, ${ }^{135}$ an international arbitral tribunal, constituted under NAFTA's Chapter 11, reviewed decisions issued by the us domestic tribunals in the area of international investment law. Much more recently, in the Avena case, the ICJ rejected the application of the procedural default doctrine of the Us law in cases concerning the violation of the Vienna Convention on Consular Relations. By so doing, the ICJ de facto reversed the us Supreme Court decision in Breard vs. Greene. ${ }^{136}$ In that case, the domestic court had considered that the procedural default rule does apply even in cases of proved violations of the Vienna Convention. In the Ferrini saga, the ICJ had to determine if the States' immunity from jurisdiction does not apply in cases where State agents have committed violations of ius cogens rules. The Italian Corte di Cassazione had already ruled over this question finding that such an exception existed. By considering the contrary, the ICJ de facto reversed the decision of the Italian Court.

The preliminary ruling of the EU law is the best example of an appeal avoiding mechanism of the judgment of domestic tribunals by an international court, which produces exactly the same consequences as the appeal itself. Therefore, it shows that "appeal looking" mechanisms are feasible and can be successful legal tools in ruling the relationship between domestic and international tribunals. Article 257 of the Treaty on the Functioning of the European Union regulates this original jurisdictional coordination mechanism. ${ }^{137}$ According to its legal design, the

134 The Sir William Peel, 72 U.S. (5 Wall.) 517 (1866) (granting restitution to British claimants whose merchant ship had been captured as prize of war by Union forces during Civil War blockade); (Robert Ahdieh, Supra, p. 2147).

135 Loewen Group, Inc. and Raymond L. Loewen v. United States of America, ICSID Case No. ARB(AF)/98/3

136 us Supreme Court, 523 U.S. 371, 378-79 (1998).

137 According to this article, "The Court of Justice of the European Union shall have jurisdiction to give preliminary rulings concerning:

(a) the interpretation of the Treaties;

(b) the validity and interpretation of acts of the institutions, bodies, offices or agencies of the Union; where such a question is raised before any court or tribunal 
preliminary ruling is centralizing questions regarding the interpretation and application of international law norms and principles at the hands of an international tribunal (the ECJ), which will tell domestic tribunals "what to do" in national contentious cases. In the same way as an appeal, the preliminary ruling procedure aims to prevent incorrect application of international law by domestic tribunals. It also seeks to preserve the uniformity of law application and interpretation in proceedings brought before tribunals pertaining to 27 different legal systems. As an appellate court's ruling, the operative part of the ECJ's judgment is binding for the domestic court that has initiated the preliminary proceeding. Even if the preliminary ruling does not amount to a judicial review, per se, the results are the same. The preliminary ruling, as an indirect appeal mechanism, supposes a vertical relationship between ECJ and EU member States' Supreme Courts. The Supreme Courts have the obligation to delegate their judicial power to the ECJ in questions concerning EU law, and the ECJ has the hierarchically superior position of an "ultimate arbiter" of the legality in the EU legal order.

Even if one does not agree with the similarity of the preliminary ruling with an appeal mechanism, the ECJ has developed another judicial doctrine that is even more intrusive than an appeal. As mentioned before, in the 2003 Kobler case, ${ }^{138}$ the ECJ recognized the responsibility of State members of the EU for breaches of EU law resulting from judicial decisions rendered by domestic judges that interpreted and applied incorrectly the Eu law. The ECJ, as a superior court, is responsible for the determination of States' international responsibility as a consequence of the judicial decision, and the Court itself can review this judgment and exam its conformity with the EU law. By so doing, in the case Commission v. Italy, ${ }^{139}$ the ECJ reviewed a definitive judgment of the Italian Supreme

of a Member State, that court or tribunal may, if it considers that a decision on the question is necessary to enable it to give judgment, request the Court to give a ruling thereon. Where any such question is raised in a case pending before a court or tribunal of a Member State against whose decisions there is no judicial remedy under national law, that court or tribunal shall bring the matter before the Court".

138 In the Köbler case, the ECJ found that States are responsible for breaches of EU law when the violation is attributable to a member State's court. The Kobler case was confirmed in the ECJ, Case C-173/03, Traghetti del Mediterraneo [2006].

139 ECJ, Case C-129/00, Commission v. Italy, 11-13 (2003). 
Court and thus, de facto, reversed the domestic tribunal's decision and demonstrated its inconformity with the EU law.

These cases show it is possible to consider that, at least in some cases, some international tribunals have developed an appeal-type of review mechanism of domestic tribunals' judgments. The benefits of the instauration of formal appeal mechanisms of national rulings before international tribunals, based on a hierarchical judicial structure, are clear. The possibility for international tribunals to review domestic judgments enhances judicial coordination between domestic and international tribunals and promotes legal predictability. Predictability is a legal value whose aim is to encourage law norms' observance by their subjects. It would be impossible to reach this aim if a law subject was exposed to inconsistent and conflicting judicial decisions on international law meaning, by domestic and international tribunals. ${ }^{140} \mathrm{~A}$ hierarchical appeal of the judgments of domestic tribunals would also permit to international courts to "backstop" domestic judges' failure to apply and interpret international law correctly. ${ }^{141}$ Ultimately, as other hierarchical tools for regulations of the relationship between domestic and international tribunals, the appeal mechanism gives to international tribunals the opportunity to adopt a single and binding interpretation of international law instead of delegating this power to states' domestic tribunals. If states want to comply with international law, they should be able to know in advance what this law means. By centralizing its interpretation in international courts that would act as appeal tribunals for domestic judgments, this legal predictability and certainty will be better preserved. It also will permit to international courts to force some issues into a debate with domestic judges on a non-voluntary basis. ${ }^{142}$

\section{Conclusion}

The continuing lack of written or unwritten de lege lata norms to rule the relationship between domestic and international tribunals is showing the complexity of the issue. Domestic legislators in national law and States' members of the international community in international

\footnotetext{
140 Caminker, "Why Must Inferior Courts Obey Superior...”.

141 Nollkaemper, "The role of domestic judgments in ICJ...", 317.

142 Ahdieh, "Between Dialogue and Decree...", 2092.
} 
law have preferred to stay silent upon this question for too many years and have put their confidence in the ability of both national and international tribunals to decide, themselves, how to regulate their jurisdictional and jurisprudential relations. The responses from the multiple domestic and international tribunals have been divergent and contradictory, and the actual pattern of judicial interaction, drawn by judges alone, is a hybrid compromise with values of diffuse horizontal comity, operating alongside with strong elements of vertical hierarchy. ${ }^{143}$ The major difference between these values has to deal with the role of judicial power in the coordination of the relations between domestic and international tribunals. True horizontal comity is contrary to any assertion or exercise of judicial power between domestic and international tribunals, ${ }^{144}$ while hierarchy always involves power cession of one tribunal to another.

As demonstrated above, there are many proofs of hierarchical "judicial power battles" in the jurisprudence of both domestic and international tribunals. In some fields, such as human rights protection or regional economic integration, international tribunals are close to winning the battle and have asserted their superiority (or supra-nationality), over domestic tribunals, regarding the interpretation and application of international law. In other fields, such as general international law, the battle continues. It is essentially a discrete and cautious battle, where judges will never speak their hierarchical concerns. However, these concerns are visible and always present whenever it comes to decide who stands in a position of authority vis-à-vis the others, domestic or international tribunals.

When international courts rule that their judgments are binding precedents and sources of law for domestic tribunals, they are affirming their judicial power and superiority toward domestic tribunals. When domestic tribunals accept this consideration, they are showing obedience to international tribunals mandates. In the same sense, when international courts directly address themselves to domestic tribunals and order them to enforce the operative part of their judgments, they are trying to impose vertical judicial power to their counterparts. If domestic courts accept to act as enforcers of the judgments of international tribunals, they are ceding power to them. Finally, when international tribunals

\footnotetext{
143 Ibid., 2034.

144 Ibid.
} 
review the conformity of a domestic judge's ruling with international law, they are assuming a role of "ultimate controller" of the respect for international law at the national and international scales.

The vertical judicial power of international courts over their domestic colleagues could be viewed as "benign power" and hierarchy as a possible tool for the regulation of the relations between domestic and international tribunals. Hierarchy promotes legal predictability and enhances the uniformity in the application and interpretation of international law at the global level. It permits the formal integration of domestic and international tribunals in a "pro-international law alliance" and in a "vertical judicial partnership" across the world. The "systemic integrity" of international law will always stay incomplete unless international tribunals were to become higher courts that can provide jurisdictional harmonization of international law, viewed as a whole. The hierarchy between domestic and international tribunals will build some type of "judicial federalism" in a "global judicial system"145 that would mark the final triumph of the supremacy of international law over domestic law. One could see this as a utopia, but a closer look at the judicial behavior of many domestic and international judges demonstrates that it can become a reality.

\section{References}

Abi-Saab, Georges. "Fragmentation or Unification: Some Concluding Remarks." New York University Journal of International Law and Politics, 31(4) (1999): 919-933.

Abi Saab, Georges. "The Normalization of International Adjudication: Convergence and Divergence." New York University Journal of International Law and Politics, 43(1) (2010): 1-14. https://nyujilp. org/wp-content/uploads/2013/02/43.1-Abi-Saab.pdf

Ahdieh, Robert B. "Between Dialogue and Decree: International Review of National Courts" New York University Law Review, 79(5)

145 Pierre Marie Dupuy, "Unité d'application du droit international à l'échelle mondiale et responsabilité des juges." European Journal of Legal Studies, 1 no. 2 (2003): 1-27. https://ejls.eui.eu/wp-content/uploads/sites/32/pdfs/Autumn_Winter2007/ Unité_d'Application_du_Droit_International_à_l'Echelle_Globale_et_\%20Responsabilité_des_Juges_.pdf 
(2004): 2029-2163. https://www.nyulawreview.org/wp-content/ uploads/2018/08/NYULawReview-79-6-Ahdieh.pdf

Alford, Roger. "The Proliferation of International Courts and Tribunals: International Adjudication in Ascendance." Proceedings of the American Society of International Law Annual Meeting, 94(2000): 160165. https://doi.org/10.1017/S027250370005549X

Alford, Roger P. "Federal Courts, International Tribunals, and the Continuum of Deference." Virginia Journal of International Law, 43(2003): 675-796.

Allard, Jullie, \& Garapon, Antoine. Les juges dans la mondialisation - la nouvelle révolution du droit. Paris: Le Seuil, 2005.

Almeida, Paula Wojcikiewicz. "Jurisdictional Immunities of the State (Germany v. Italy): The International Court of Justice against the Evolution of International Law." Anuario Colombiano de Derecho Internacional (acdi), 11 (2018): 21-70. https://doi.org/10.12804/revistas.urosario.edu.co/acdi/a.6538

Alvarez, Jose E. "The New Dispute Settlers: (Half) Truths and Consequences." Texas International Law Journal, 38(3) (2003): 405-455.

Mexico, Suprema Corte de Justicia. Amparo Directo 517/2011. https:// www.scjn.gob.mx/sites/default/files/proyectos_resolucion_scjn/ documento/2016-10/ADR-517_2011_1.pdf

Argentina, Supreme Court of Justice. Esposito, Miguel Angel s/ motion of statute of limitation of the criminal proceeding brought by his defense, 23 December 2004, (Case file 224.XXXIX).

D'Aspremont, Jean. "The Systemic Integration of International Law by Domestic Courts: Domestic Judges as Architects of the Consistency of the International Legal Order". In The Practice of International and National Courts and the (De-)Fragmentation of International Law, edited by Ole Kristian Fauchald and André Nollkaemper, 141-165. Oxford: Hart Publishing, 2012.

du Bois de Gaudusson, Jean. "La complexité de la participation des Cours suprêmes des pays en voie de développement au dialogue des juges." Petites affiches, (112), June 4, 2008, 22.

Burke-White, William W. "A Community of Courts: Toward a System of International Criminal Law Enforcement." Michigan Journal of International Law, 24(1) (2002): 1-104. https://repository.law.umich. $\mathrm{edu} / \mathrm{mjil} / \mathrm{vol} 24 /$ iss $1 / 1 /$ 
Caminker, Evan. "Why Must Inferior Courts Obey Superior Court Precedents?". Stanford Law Review, 46(4) (1994): 817-873. https:// doi.org/10.2307/1229094

Cançado Trindade, Antonio Augusto. La expansión de la jurisdicción internacional y su importancia para la realización de la justicia. http://legal. un.org/avl/ls/Cancado-Trindade_HR_video_2.html

Cassese, Antonio. "Remarks on Scelle's Theory of "Role Splitting" (dédoublement fonctionnel) in International Law." European Journal of International Law, 1 (1990): 210-231. http://www.ejil.org/ pdfs/1/1/1126.pdf

European Court of Human Rights. Johnston and others v. Ireland, Application 9697/82, December 18, 1986. http://hudoc.echr.coe.int/eng?i=00157508

Article 1904 Binational Panel Review Pursuant of the North American Free Trade Agreement in the Matter of Certain Softwood Lumber Products from Canada: Final Determinative Antidumping Determination, June 9, 2005. http:// www.sice.oas.org/dispute/nafta/english/UC02190402Ce.pdf

Chanet, Christine. "Les influences croisées entre les juridictions nationales et les juridictions internationales.” Les Cabiers de Droit, 51(1) (2010): 223-232. https://doi.org/10.7202/044141ar

Claes, Monica y de Visser, Maartje. "Are You Networked Yet? On Dialogues in European Judicial Networks." Utrecht Law Review, 8(2) (2012): 100-114. http://doi.org/10.18352/ulr.197

Conseil d'Etat, décision, 18/06/2008, Gestas.

Costa Rica, Constitutional Chamber of the Supreme Court of Justice. Constitutional Motion, Opinion 2313-95 (Case File 0421-S-90), 9 May 1995.

Dickinson, Laura A. "Using Legal Process to Fight Terrorism: Detentions, Military Commissions, International Tribunals, and the Rule of Law." South Carolina Law Review, 75 (2002): 14071492. https://southerncalifornialawreview.com/wp-content/ uploads/2018/01/75_1407.pdf

Supreme Court of Justice of the Dominican Republic, Resolution $\mathrm{N}^{\circ}$ 1920-2003, 13 November 2003.

Dupuy, Pierre Marie. "Unité d'application du droit international à l'échelle mondiale et responsabilité des juges." European Journal of Legal Studies, 1(2) (2003): 1-27. https://ejls.eui.eu/ wp-content/uploads/sites/32/pdfs/Autumn_Winter2007/ 
Unité_d'Application_du_Droit_International_à_l'Echelle_Globale_et_\%20Responsabilité_des_Juges_.pdf

de Dycker, Stephanie. "Private International Law Disputes Before the International Court of Justice." Journal of International Dispute Settlement, 1(2) (2010): 475-498. https://doi.org/10.1093/jnlids/idq006 ECJ, Köbler vs. Austria (2003) C-224/01.

Ferrer Mac-Gregor, Eduardo. "Interpretación conforme y control difuso de convencionalidad. El nuevo paradigma para el juez mexicano". In La reforma constitucional de derechos humanos. Un nuevo paradigma edited by Miguel Carbonell y Pedro Salazar, 339-349. Mexico: Universidad Nacional Autónoma de México, 2012.

Frydman, Benoit. "Le dialogue international des juges et la perspective idéale d'une justice universelle." In Le dialogue des juges, Actes $d u$ colloque du 28 avril 2006, Bruxelles: Bruylant, 2007.

Fuenzalida Bascuñán, Sergio. "La jurisprudencia de la Corte Interamericana de Derechos Humanos como fuente de derecho. Una revisión de la doctrina del "examen de convencionalidad". Revista de Derecho (Valdivia), 28(1) (2015): 171-192. https://doi.org/10.4067/ S0718-09502015000100008

Gattini, Andrea. "Domestic Judicial Compliance with International Judicial Decisions: Some Paradoxes." From Bilateralism to Community Interest: Essays in Honour of Bruno Simma, edited by Ulrich Fastenrath, Rudolf Geiger, Daniel-Erasmus Khan, Andreas Paulus, Sabine von Schorlemer, and Christoph Vedder, 1168-1188. Oxford University Press, 2011.

Guillaume, Gilbert. "The Future of International Judicial Institutions." The International and Comparative Law Quarterly, 44(4) (1995): 848862.

Guillaume, Gilbert. "Advantages and Risks of Proliferation, A Blueprint for Action.” Journal of International Criminal Justice, 2(2) (2004): 300303. https://doi.org/10.1093/jicj/2.2.300

Graewert, Tim. "Conflicting Laws and Jurisdiction in the Dispute Settlement Process of Regional Trade Agreements and the wto." Contemporary Asia Arbitration Journal, 1(2) (2008): 287-334. https://www.ilsa.org/Jessup/Jessup2020/Basic\%20Materials/Graewart $\% 2$ C $\% 201 \% 282 \% 29 \% 20$ Contemp. $\% 20$ Asia $\% 20$ Arb.\%20J.\%20287.pdf 
Heifer, Laurence R., \& Slaughter, Anne-Marie. “Toward a Theory of Effective Supranational Adjudication.” The Yale Law Journal, 107(2) (1997): 273-391.

Helfer, Laurence R. “Overlegalizing Human Rights: International Relations Theory and the Commonwealth Caribbean Backlash Against Human Rights Regimes." Columbia Law Review, 102(7) (2002): 1832-1911.

l'Heureux-Dubré, Claire. «The Importance of Dialogue: Globalization and the International Impact of Rehnquist Court». Tulsa Law Journal, 34(1) (1998): 15-40.

Huneeus, Alexandra. "Courts resisting Courts: Lessons from the InterAmerican Court's struggle to enforce Human Rights", Cornell International Law Journal, 44 no. 3 (2011): 493-533. https://scholarship.law.cornell.edu/cilj/vol44/iss3/2

IACHR, Opinión consultiva OC-16/99, "El derecho a la información sobre la asistencia consular en el marco de las garantías del debido proceso legal", 1st of November 1999, http://www.cidh.org/migrantes/ Opini\%C3\%B3n\%20Consultiva\%2016.htm

IACHR, Apitz-Barbera et al. vs. Venezuela, 5 August 2008.

IACHR, Almonacid-Arellano et al v. Chile, 26 September 2006 (Preliminary Objections, Merits, Reparations and Costs).

IACHR, Gelman Vs. Uruguay, 24 February 2011, 2006 (Preliminary Objections, Merits, Reparations and Costs).

IACHR, Cabrera García y Montiel Flores Vs. México, 26 November 2010.

ICJ, Case concerning the Application of the Convention on the Prevention and Punishment of the Crime of Genocide, Bosnia and Herzegovina vs. Serbia and Montenegro, February 26, 2007, http://www.icj-cij.org/docket/ files/91/13685.pdf

ICJ, Military and Paramilitary Activities in Nicaragua, June 27, 1986, http:// www.icj-cij.org/docket $/$ index.php? sum $=367 \&$ code $=$ nus $\& p 1=3 \&$ $\mathrm{p} 2=3 \&$ case $=70 \& \mathrm{k}=66 \& \mathrm{p} 3=5$

ICJ, Avena, México vs. United States, March 31, 2004, en http://www. icj-cij.org/docket/files/128/8188.pdf

ICJ, Jurisdictional Immunities of the State, (Germany v Italy), 3rd February 2012.

ICJ, Fisheries Jurisdiction, United Kingdom v Iceland, Merits, Judgment, 25 July 1974. 
ICJ, Legality of the Threat or Use of Nuclear Weapons, Advisory Opinion, 8 July 1996.

ICJ, Asylum, Colombia v Peru, Merits, Judgment, 20 November 1950.

ICJ, Haya de la Torre Case, Colombia v Peru, Merits, 13th June 1951.

ICJ, Difference Relating to Immunity from Legal Process of a Special Rapporteur of the Commission on Human Rights, (Advisory Opinion), 29th April 1999.

ICJ, LaGrand, Germany v United States, Judgment, Jurisdiction, Admissibility, Merits, 27th June 2001.

ICJ, Case Concerning the Arrest Warrant of 11 April 2000 (Democratic Republic of Congo v Belgium) Judgment, Merits, Preliminary Objections, 14th February 2002, para 78 .

ICJ, Certain Criminal Proceedings in France (Republic of the Congo v. France). Overview of the case, https://www.icj-cij.org/en/case/129

ICJ, Jurisdiction and Enforcement of Judgments in Civil and Commercial Matters (Belgium v. Switzerland), Overview of the Case, https://www. icj-cij.org/en/case/145

ICJ, Jurisdiction and Enforcement of Judgments in Civil and Commercial Matters (Belgium v. Switzerland), Overview of the Case, https://www. icj-cij.org/en/case/145

ICJ, Questions relating to the Obligation to Prosecute or Extradite (Belgium v. Senegal), Overview of the Case, https://www.icj-cij.org/en/case/144

ICTY, Prosecutor vs. Radovan Karadzic, indictment "Srebrenica", November 24, 1995; indictment "Bosnia and Herzegovina”, July 24, 1995, http://www.icty.org/case/karadzic/4

ICTY, Prosecutor vs. Tadic, May 7, 1997, http://www.icty.org/x/cases/ tadic/tjug/en/tad-tsj70507JT2-e.pdf; Appeal Chamber Decisions, July 15, 1999, http://www.icty.org/x/cases/tadic/acjug/en/tadaj990715e.pdf

ICTY, Kupreskic et. al., 14 January 2000.

Italian Constitutional, Court No. 238, 22 October 2014.

Italian Supreme Court, Case number 5044, Luigi Ferrini vs. Germany, 11 march 2004.

ITLOS, Case 7: Case concerning the Conservation and Sustainable Exploitation of Swordfish Stocks in the South-Eastern Pacific Ocean (Chile/European Union), order 2/2003, December 20, 2000.

ITLOS, United States-Investigation of the International Trade Commission in Softwood Lumber from Canada, Recourse by Article 25.1 of the DSU by Canada-Report by Panel, May 9, 2006; Re Matter of Certain Softwood 
Lumber Products from Canada (opinion and Order), NAFTA, Extraaordinary Challenge Committee, August, 10, 2005.

ITLos, Mox Plant Case, Irlanda c. el Reino Unido, 13 de noviembre de 2001, CJE, Mox Plant Case, Commission vs. Irland, case C-459/03, May 30, 2006.

Jennings, Robert. "The Proliferation of Adjudicatory Bodies: Dangers and Possible Answers in Implications of the Proliferation of International Adjudicatory Bodies for Dispute Resolution." American Society of International Law Bulletin, 7(1995).

Kastellec, Jonathan. The Judicial Hierarchy: A Review Essay. Oxford Research Encyclopedia of Politics. https://doi.org/10.1093/acrefore/9780190228637.013.99

Kelsen, Hans. Pure theory of law. Berkeley: University of California Press, 1967.

Koskenniemi, Martti. "Hierarchy in International Law: A Sketch.” European Journal of International Law, 8 (1997): 566-582. http://www.ejil. org/pdfs/8/4/785.pdf

$\mathrm{Ku}$, Julian G. "International Delegations and the New World Court Order." Washington Law Review, 81 no. 1 (2006): 1-70. https:// digitalcommons.law.uw.edu/wlr/vol81/iss1/2

Leathely, Christian. "An institutional hierarchy to combat the fragmentation of international law: has the ILC missed an opportunity?" International Law and Politics, 40 (2007): 259-306. http://repositoriocdpd.net:8080/handle/123456789/640

Martínez, Jenny. "Towards and International Judicial System." Standford Law Review, 56 no. 2 (2003): 429-529.

Martinico, Giuseppe, \& Carrozza, Paolo (Eds.). Shaping Rule of Law through Dialogue. International and Supranational Experiences. Groningen: Europa Law Publishing, 2010.

Mexican Supreme Court of Justice, Contradicción de tesis 293/2011

Nollkaemper, André. "Conversations Among Courts, Domestic and International Adjudicators." In The Oxford Handbook of International Adjudication, edited by Cesare Romare, Karen Alter and Yuval Shany. Oxford University Press, 2015. https://doi.org/10.1093/ law/9780199660681.003.0024

Nollkaemper, André. "The Role of Domestic Courts in the Case Law of the International Court of Justice.", Chinese Journal of International Law, 5 no. 2 (2006): 301-322. https://doi.org/10.1093/chinesejil/ jm1027 
Oellers-Frahm, Karin. "Multiplication of International Courts and Tribunals and Conflicting Jurisdiction- Problems and Possible Solutions." Max Planck Yearbook of United Nations Law, 5 (2001): 67-104. https://www.mpil.de/files/pdf1/mpunyb_oellers_frahm_5.pdf

Orrego Vicuña, Francisco, \& Pinto, Christopher. The Peaceful Settlement of Disputes: Prospects for the Twenty First Century, Preliminary Report Prepared for the 1999 Centennial of the First Peace Conference. CAHDI, 1998.

Orrù, Romano. Informal Judicial Cross-Fertilization and the System of Conferences Between Constitutional Courts and Equivalent Bodies. http://www. juridicas.unam.mx/wccl/ponencias/12/206.pdf

Fulvio, Maria Palombino. "Compliance with International Judgments: Between Supremacy of International Law and National Fundamental Principles." ZaöRV, 75 (2015): 503-529. https://www. zaoerv.de/75_2015/75_2015_3_a_503_530.pdf

PCA, Mox Plant Case, Ireland vs. UK, June 23, 2003.

Constitutional Tribunal of Peru, (case file $\mathrm{N}^{\circ}$ 2730- 2006-PA/TC), 21 July 2006.

Petrova Georgieva, Virginia. “La 'judicialización': una nueva característica del orden jurídico internacional". Anuario Mexicano de Derecho Internacional, 15 no. 1 (2015): 3-45. https://doi.org/10.1016/j. amdi.2015.06.001

Reinisch, August. "The Use and Limits of Res Judicata and Lis Pendens as Procedural Tools to Avoid Conflicting Dispute Settlement Outcomes." Law and Practice of International Courts and Tribunals, 3 no. 1 (2004): 37-77. https://doi.org/10.1163/157180301773732627

Romano, Cesare. "Deciphering the Grammar of the International Jurisprudential Dialogu." New York University Journal of International Law and Politics, 41 no. 4 (2010): 755-787. http://cesareromano.com/ wp-content/uploads/2015/05/Romano-Dechiphering-Grammarof-the-Jurisprudential-International-Dialogue.pdf

Romano, Cesare, Alter, Karen, \& Shany, Yuval. The Oxford Handbook of International Adjudication. Oxford University Press, 2015.

Shany, Yuval. Regulating Jurisdictional Relations Between National and International Tribunals. Oxford University Press, 2009.

Silva Abbot, Max. "Control de convencionalidad interno y jueces locales: un planteamiento defectuoso". Estudios Constitucionales, 14 no. 2 (2016): 101-142. https://doi.org/10.4067/S071852002016000200004 
Slaughter, Anne-Marie. "A Typology of Transjudicial Communication." University of Richmond Law Review, 29 no. 1 (1995): 99-137. https:// scholarship.richmond.edu/cgi/viewcontent.cgi?article $=2120 \& \mathrm{c}$ ontext=lawreview

Slaughter, Anne-Marie. "Judicial Globalization." Virginia Journal of International Law, 40 no. (1999): 1103-1124. https://scholar.princeton. edu/sites/default/files/slaughter/files/vjil.pdf

Slaughter, Anne-Marie. A New World Order. Princeton University Press, 2005.

Slaughter, Anne-Marie. "Sovereignty and Power in a Networked World Order." Standford Journal of International Law, 40 (2004): 283-327. https://scholar.princeton.edu/sites/default/files/slaughter/files/ stanford.pdf

Slaughter, Anne-Marie. "A Brave New Judicial World." In American Exceptionalism and Human Rights, edited by Ignatieff, Michael, 277303. Princeton University Press, 2005. https://doi.org/10.2307/j. ctt7skx6.12

Sloss, David, \& Van Alstine, Michael. International Law in Domestic Courts. 2015. http://digitalcommons.law.scu.edu/facpubs/889

Tsanakopoulos, Antonios. "Domestic Courts in International Law: The International Judicial Function of National Courts." Loyola of Los Angeles International \& Comparative Law Review, 34 (2011): 133-168. https://ssrn.com/abstract $=1861067$

US Supreme Court, Medellin vs. Texas, 552 U.S. 491 (2008).

US Supreme Court, Sanchez-Llamas v. Oregon, 548 U.S. 331 (2006).

Venezuelan Supreme Court, decisión No. 1939 del 18 de diciembre de 2008.

Waters, Melissa. "Mediating Norms and Identity: The Role of Transnational Judicial Dialogue in Creating and Enforcing International Law." Georgetown Law Journal, 93 no. 2 (2005): 487-574. https:// ssrn.com/abstract $=794767$

Webb, Philippa. International Judicial Integration and Fragmentation. Oxford University Press, 2013.

WTO, Chile-Measures Affecting the Transit and Importation of Swordfish, Request for the Establishment of a Panel by the European Communities, November 7,2000.

2 BvR 2115/01, Judgment, 19 September, 2006.

Ziccardi Capaldo, Giuliana. The Pillars of Global Law. New York: AshgatePublishing, 2008. 